\title{
Influence of chemosynthetic ecosystems on nematode community structure and biomass in the deep eastern Mediterranean Sea
}

\author{
N. Lampadariou ${ }^{1}$, V. Kalogeropoulou ${ }^{1}$, K. Sevastou ${ }^{1}$, K. Keklikoglou ${ }^{2}$, and J. Sarrazin ${ }^{3}$ \\ ${ }^{1}$ Hellenic Centre for Marine Research, P.O. Box 2214, 71003 Heraklion, Crete, Greece \\ ${ }^{2}$ Department of Biology, University of Crete, P.O. Box 2208, 71409 Heraklion, Crete, Greece \\ ${ }^{3}$ Ifremer Brest, REM/EEP, Institut Carnot Ifremer-EDROME, BP 70, 29280 Plouzané, France
}

Correspondence to: N. Lampadariou (nlamp@hcmr.gr)

Received: 29 November 2012 - Published in Biogeosciences Discuss.: 14 December 2012

Revised: 28 June 2013 - Accepted: 3 July 2013 - Published: 9 August 2013

\begin{abstract}
Mud volcanoes are a special type of cold seeps where life is based on chemoautotrophic processes. They are considered to be extreme environments and are characterized by unique megafaunal and macrofaunal communities. However, very few studies on mud volcanoes taking into account the smaller meiobenthic communities have been carried out. Two mud volcanoes were explored during the MEDECO (MEditerranean Deep-sea ECOsystems) cruise (2007) with the remotely operated vehicle (ROV) Victor-6000: Amsterdam, located south of Turkey between 1700 and $2000 \mathrm{~m}$ depth (Anaximander mud field); and Napoli, south of Crete, located along the Mediterranean Ridge at about $2000 \mathrm{~m}$ depth (Olimpi mud field). The major aim of this study was to describe distributional patterns of meiofaunal communities and nematode assemblages from different seep microhabitats. Meiofaunal taxa and nematode assemblages at both mud volcanoes differed significantly from other Mediterranean sites in terms of standing stocks, dominance and species diversity. Density and biomass values were significantly higher at the seep sites, particularly at Amsterdam. Patterns of nematode diversity, the dominant meiofaunal taxon, varied, displaying both very high or very low species richness and dominance, depending on the microhabitat studied. The periphery of the Lamellibrachia and bivalve shell microhabitats of Napoli exhibited the highest species richness, while the reduced sediments of Amsterdam yielded a species-poor nematode community dominated by two successful species, one belonging to the genus Aponema and the other to the genus Sabatieria. Analysis of $\beta$-diversity showed that microhabitat heterogeneity of mud volcanoes contributed substantially to the total nematode species richness in the eastern Mediter-
\end{abstract}

ranean Sea. These observations indicate a strong influence of mud volcanoes and cold-seep ecosystems on the meiofaunal communities and nematode assemblages.

\section{Introduction}

Cold seeps are characterized by the flow of reduced chemical compounds from the subsurface to the seafloor, but, in contrast to hot vents, they are not directly associated with high thermal anomalies (Sibuet and Olu, 1998; Tunnicliffe et al., 2003). They have been known for over $30 \mathrm{yr}$ (Paull et al., 1984; Suess et al., 1985) and occur in a wide variety of geological settings along both active and passive margins (Sibuet and Olu, 1998; Levin, 2005). They are commonly found in the Pacific, Atlantic and Indian oceans and are known to host highly diverse and abundant chemosynthetically-based communities (Carney, 1994). More recently, seep communities have been also reported in the Mediterranean Sea (Corselli and Basso, 1996; Holland et al., 2003, 2006; Loncke and Mascle, 2004; Camerlenghi and Pini, 2009; Savini et al., 2009).

Submarine mud volcanoes are a special type of cold seep where over-pressuried sediment leaks from deeper layers in the form of mud and fluid through the sea floor (Milkov, 2000; Dimitrov, 2002). These are often accompanied by large quantities of gas emissions, such as methane, commonly originating from deep, subsurface sedimentary layers located several kilometers deep (Milkov, 2000; Kopf, 2002). These gas emissions are taken up by archaea and bacteria through chemoautotrophic processes to produce sulfides, 
which may be further utilized by symbiotic bacteria to sustain high biomass production in invertebrates (Fiala-Médioni and Felbeck, 1990; Fisher, 1990; Olu-Le Roy et al., 2004). The study of submarine mud volcanoes, similarly to other dysoxic, hypoxic and sulphidic environments of the deep sea, has attracted a lot of attention over the last decades since they may provide useful insights into early metazoan life (e.g. Bernhard et al., 2000; Van Dover, 2000; Danovaro et al., 2010). This is because these environments are believed to resemble the late Archaean or Proterozoic Eons, when oxygen levels were low and the origin and initial diversification of Eucarya occurred (Knoll and Holland, 1995).

Most biological studies of cold seeps and submarine mud volcanoes have focused on large, symbiont-bearing megafauna, such as siboglinid tubeworms, mytilid mussels and vesicomyid clams (Sibuet and Olu, 1998; Kojima, 2002; Sibuet and Olu-LeRoy, 2002; Tunnicliffe et al., 2003; Levin and Mendoza, 2007), or on microbiological processes (Valentine and Reeburgh, 2000; Hinrichs and Boetius, 2002; Valentine, 2002). Several studies have also examined the smaller infaunal communities (predominantly macrofauna), suggesting that their densities may be higher or similar compared to non-seep communities (Davis and Spies, 1980; Levin et al., 2000, 2003; Levin and Mendoza, 2007; Menot et al., 2010). Recently, such studies have also included the eastern Mediterranean (Ritt et al., 2011, 2012). On the other hand, meiofauna studies of seep areas, particularly mud volcanoes, are generally scarce, and until the very recent studies of Zeppilli et al. (2011a, 2012) such studies were completely absent from the Mediterranean. Previous studies, mainly from the Arctic, the Gulf of Mexico, Barbados and the Japan Trench, have reported that, similar to macrofauna, there is no unequivocal response of the metazoan meiofauna to the different seep conditions (Shirayama and Ohta, 1990; Olu et al., 1997; Buck and Barry, 1998; Levin, 2005). The increased habitat heterogeneity found in cold-seep areas often results in an unpredictable high variability of meiofaunal densities within the seeps, relative to the surrounding sediment (Montagna and Spies, 1985; Levin, 2005; Cordes et al., 2010; Ritt et al., 2012). With regard to nematode diversity, the results were inconsistent, with some studies showing an exceptionally high dominance of only one species (Van Gaever et al., 2006) while others reported a species-rich community with many overlapping families or genera between seep and nearby control sediments (Shirayama and Ohta, 1990; Pape et al., 2011). Nevertheless, in most of these studies, dominance was usually higher and species diversity was lower when compared to surrounding pristine areas (Shirayama and Ohta, 1990; Van Gaever et al., 2006, 2010).

The present study provides a detailed quantitative analysis of the meiofauna communities from two different mud volcanoes in the eastern Mediterranean: Amsterdam and Napoli. They were the target of an interdisciplinary cruise, MEDECO (MEditerranean Deep-sea ECOsystems) carried out in 2007, whereby one of the main objectives was to investigate the mi- crobial as well as the meio-, macro- and megafaunal communities from several reduced deep-water environments including mud volcanoes, brine seeps and pockmark areas along the Mediterranean Sea. Previously, Ritt et al. (2012) described the structure of macrofaunal communities $(>250 \mu \mathrm{m})$ in relation to the environmental conditions of the two mud volcanoes. Regarding the meiofauna $(32-1000 \mu \mathrm{m})$, the main objective of the cruise was to quantify the communities from different microhabitats in terms of species diversity, abundance and biomass, with a special focus on nematodes, the most abundant group. The various microhabitats were chosen on the basis of differences in appearance as evidenced both from observations with the ROV Victor-6000 as well as from previous observations during the MEDINAUT cruise in 1998. The microhabitats studied included soft sediments with high density of bivalve shells, areas with carbonate crusts, areas with high densities of the siboglinid polychaete Lamellibrachia anaximandri as well as highly reduced sediments with visible bubble emissions.

More specifically, the following questions were addressed:

1. Are meiofaunal standing stocks as well as local (alpha) diversity enhanced in mud volcanoes compared to nearby deep-sea sediments?

2. Do different mud volcanoes harbour distinct and specialized meiofauna/nematode communities and are they different from adjacent deep-sea sediments?

\section{Materials and methods}

\subsection{Study areas and microhabitats}

Sediment samples were collected during Leg 1.3 of the MEDECO cruise aboard the French R/V Pourquoi Pas?, which was equipped with the remotely operated vehicle (ROV) Victor-6000. This leg of the cruise took place between 18 and 31 October, 2007. In total, nine different microhabitats were sampled: four each from the Amsterdam and Napoli mud volcanoes and one from an area located a few miles from the centre of Amsterdam mud volcano in the wider area of the Anaximander mud field, hereafter referred to as the far periphery microhabitat (Pfar). The microhabitats from the Amsterdam mud volcano were (i) brown sediments with high density of bivalve shells (Biv); (ii) the periphery of carbonate crusts (Pcc); (iii) a gas emission area, hereafter referred to as the reduced sediment area (Red); and (iv) the summit of the mud volcano (Top). The four microhabitats from the Napoli mud volcano were (i) brown sediments with bivalve shells (Biv); (ii) the Lamellibrachia microhabitat (Lam); (iii) the periphery of the carbonate crusts (Pcc); and (iv) the periphery of the Lamellibrachia microhabitat (Plam). A detailed description of the two areas and their microhabitats as well as of the sampling methodology follows. 


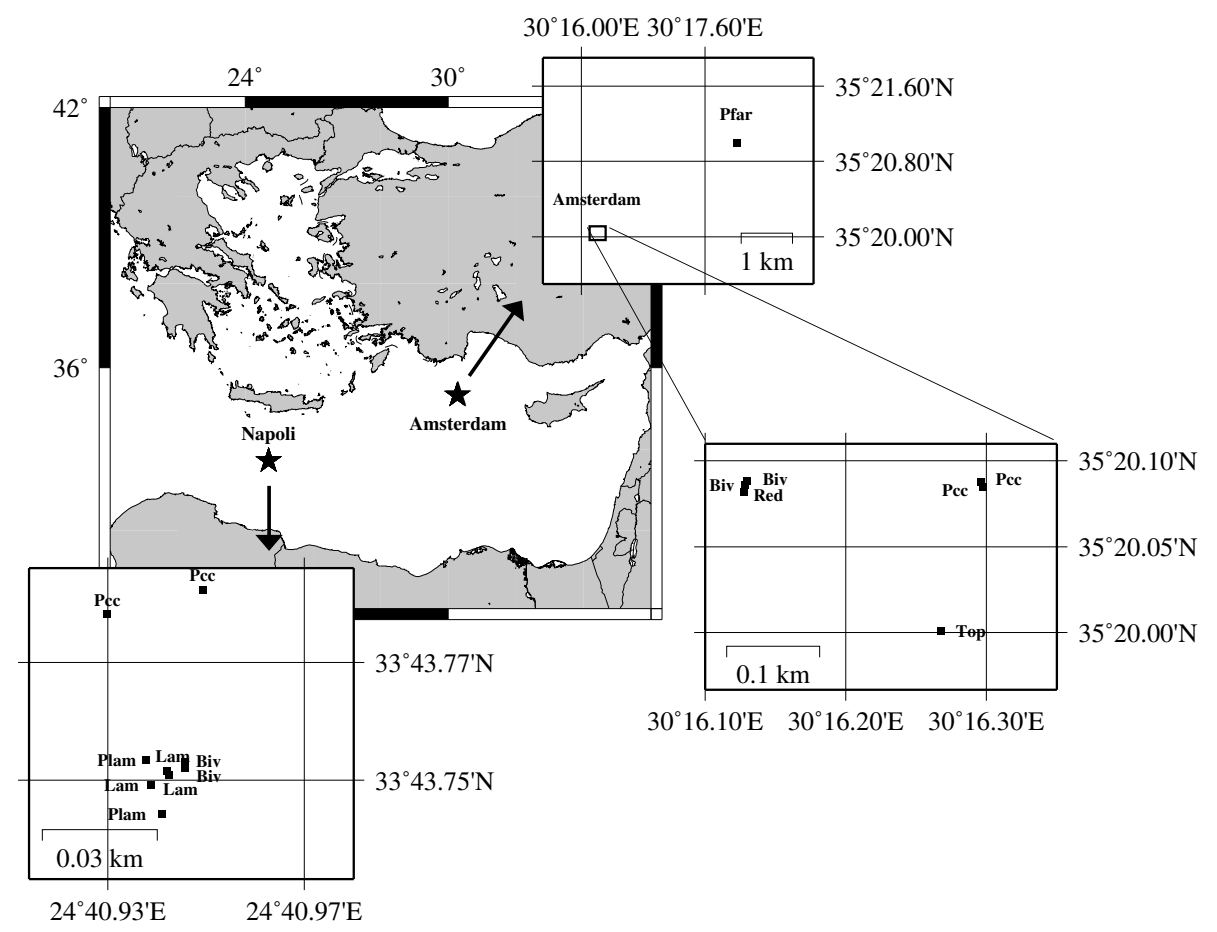

Fig. 1. General map of the eastern Mediterranean Sea with the location (black stars) of the two mud volcanoes, Amsterdam and Napoli. Zoom-view maps show detailed positions of the different microhabitats: (Biv: bivalve shells; Pcc: periphery of carbonate crusts; Red: reduced sediments; Top: summit of the mud volcano; Lam: Lamellibrachia microhabitat; Plam: periphery of Lamellibrachia; Pfar: far periphery).

\subsubsection{Amsterdam mud volcano}

Amsterdam is an elliptical seafloor feature, up to $3 \mathrm{~km}$ wide and $100 \mathrm{~m}$ high, located in the area southwest of Turkey (Fig. 1). It has a very rough morphology with depressions and abrupt scarps, particularly on its summit ( $2040 \mathrm{~m}$ depth) due to an erupted mud flow over $300 \mathrm{~m}$ thick. The substratum is characterized by the presence of carbonate crusts, muddy areas and rock clasts (i.e. rock fragments that come from deeper layers and are expulsed on the seafloor with fluid/gas emissions). Temperature measurements in the centre of this mud volcano support the presence of a high seepage activity, with the temperature reaching $36^{\circ} \mathrm{C}, 7 \mathrm{~m}$ deep within the sediments (Foucher unpublished data, MEDECO 2007). No brine pools have ever been observed for Amsterdam (Zitter et al., 2005). Bivalve shells and tubeworms have been seen close or under carbonate crusts.

Regarding the four microhabitats sampled from Amsterdam, the carbonate crusts presented different morphologies consisting of larger or smaller pavements located both on the surface but also within the sediments. Samples were obtained from a distance of approximately $4 \mathrm{~m}$ from the crusts, hereafter referred to as the periphery of the carbonate crusts (Pcc). The bivalve shell microhabitat (Biv) on the other hand, consisted of soft sediments covered by large numbers of small bivalves from 2 families (Mytilidae and Vesicomyidae). In some cases, this microhabitat was characterized by large pieces of carbonate crust covered with dead mussels belonging to the genus Idas instead. Infrequent live specimens of Lamellibrachia were visible as well. The reduced sediments (Red) microhabitat was an interesting active site where gentle gas emissions were observed. The summit of the mud volcano (Top) was also sampled; however, it was completely covered with large amounts of clasts of various types (both small and large) and therefore sampling was only possible by means of the box corer. Two pseudo-replicates were obtained from this area by sub-sampling one USNEL box core deployment. A summary of station parameters, microhabitat type and number of samples obtained from the Amsterdam mud volcano is provided in Table 1.

A peripheral site (Pfar), located approx. $2 \mathrm{nmi}$ to the northeast of Amsterdam, was also sampled (Fig. 1). Only one sample could be obtained from one multiple corer deployment.

\subsubsection{Napoli mud volcano}

Napoli is a dome-shaped feature, $1000 \mathrm{~m}$ wide and $200 \mathrm{~m}$ high, located south of Crete. It is located at $1950 \mathrm{~m}$ depth and is commonly surrounded by irregular mud flows and circular depressions. Fresh mud flows and brine pools were observed on the summit, indicating intense degassing (Charlou et al., 2003). Brines are formed by salt-bearing sediments dissolved by warm fluids. Therefore, brine seepage to the seafloor is a result of fluid release along faults piercing 
Table 1. Station information showing microhabitat type, position, depth, dive number of the ROV and sample code. Samples collected from the same type of microhabitats were treated as replicate samples (Biv: bivalve shells; Pcc: periphery of carbonate crusts; Red: reduced sediments; Top: summit of the mud volcano; Lam: Lamellibrachia microhabitat; Plam: periphery of Lamellibrachia; Pfar: far periphery).

\begin{tabular}{|c|c|c|c|c|c|c|}
\hline Area & Habitat type & Latitude (N) & Longitude (E) & Depth (m) & Operation & Sample code \\
\hline \multirow[t]{6}{*}{ Amsterdam } & \multirow[t]{2}{*}{ Biv } & $35^{\circ} 20.0861$ & $30^{\circ} 16.1280$ & 2024 & Dive: $334-13$ & CT-11 \\
\hline & & $35^{\circ} 20.0883$ & $30^{\circ} 16.1298$ & 2024 & Dive: $334-13$ & CT-05 \\
\hline & \multirow[t]{2}{*}{ Pcc } & $35^{\circ} 20.0848$ & $30^{\circ} 16.2977$ & 2025 & Dive: $334-13$ & CT-14 \\
\hline & & $35^{\circ} 20.0876$ & $30^{\circ} 16.2960$ & 2025 & Dive: $334-13$ & CT-15 \\
\hline & Red & $35^{\circ} 20.0816$ & $30^{\circ} 16.1278$ & 2025 & Dive: $334-13$ & CT-04 \\
\hline & Top & $35^{\circ} 20.0010$ & $30^{\circ} 16.2679$ & 2029 & Box corer: KGS-22 & KGS-22A \\
\hline \multirow[t]{9}{*}{ Napoli } & \multirow[t]{2}{*}{ Biv } & $33^{\circ} 43.7517$ & $24^{\circ} 40.9464$ & 1943 & Dive: $330-9$ & CT-18 \\
\hline & & $33^{\circ} 43.7526$ & $24^{\circ} 40.9465$ & 1943 & Dive: $330-9$ & CT-19 \\
\hline & \multirow[t]{3}{*}{ Lam } & $33^{\circ} 43.7493$ & $24^{\circ} 40.9407$ & 1942 & Dive: $330-9$ & CT-13 \\
\hline & & $33^{\circ} 43.7507$ & $24^{\circ} 40.9437$ & 1942 & Dive: $330-9$ & CT-07 \\
\hline & & $33^{\circ} 43.7514$ & $24^{\circ} 40.9434$ & 1943 & Dive: $330-9$ & CT-10 \\
\hline & \multirow[t]{2}{*}{ Pcc } & $33^{\circ} 43.7735$ & $24^{\circ} 40.9333$ & 1941 & Dive: $331-10$ & CT-27 \\
\hline & & $33^{\circ} 43.7770$ & $24^{\circ} 40.9494$ & 1941 & Dive: $331-10$ & CT-25 \\
\hline & \multirow[t]{2}{*}{ Plam } & $33^{\circ} 43.7452$ & $24^{\circ} 40.9426$ & 1943 & Dive: $331-10$ & CT-31 \\
\hline & & $33^{\circ} 43.7528$ & $24^{\circ} 40.9399$ & 1942 & Dive: $331-10$ & CT-29 \\
\hline Anax. mud field & Pfar & $35^{\circ} 20.9970$ & $30^{\circ} 18.0057$ & 2152 & Multicorer: MTB-5 & MTB-5 \\
\hline
\end{tabular}

the evaporites. The muddy brines are often rich in thermogenic and biogenic hydrocarbon gases produced below the evaporites. On this mud volcano, benthic communities (e.g. tubeworms, bivalves) were observed at the periphery of the centre, avoiding the proximity of brines where the salinity can reach up to $83 \mathrm{~g} \mathrm{~L}^{-1}$ salt (Charlou et al., 2003). During the MEDECO cruise (2007), many empty brines and "dried" brine rivers were surveyed on the flanks, which were considered to be fossil brines. The brine pools reported during previous cruises (MEDINAUT 2000, NAUTINIL 2003) were not re-observed during MEDECO, suggesting that fluid/gas emissions are variable in time and space.

Regarding the four microhabitats sampled from Napoli, the Lamellibrachia area was characterized by black sediments where dense, bush-like clusters of the tubeworm Lamellibrachia anaximandri occurred. Samples were obtained from two different areas: (i) from patches of brown, normal-looking sediment found in the immediate vicinity (less than $1 \mathrm{~m}$ distance) of the tubeworms, hereafter referred to as the Lamellibrachia microhabitat (Lam); and (ii) from a distance of approximately $7 \mathrm{~m}$ from the tubeworms, hereafter referred to as the periphery of the Lamellibrachia (Plam). The bivalve shell area (Biv) consisted of large numbers of dead bivalve shells belonging mainly to the family Lucinidae. Finally, the carbonate crusts of Napoli formed large and thick pavements on the surface and also within the sediments and were difficult to sample. Therefore only their periphery, an area approximately $4 \mathrm{~m}$ away, hereafter referred to as the periphery of the carbonate crusts (Pcc), was sampled. Table 1 provides a summary of station parameters, microhabitat type and number of samples obtained from the Napoli mud volcano.

\subsection{Sampling and sample processing}

Most samples were collected by means of video-guided push cores using the ROV Victor-6000; the exceptions being the Top and the Pfar microhabitats, which were sampled by means of a USNEL box corer and a multiple corer, respectively. All samples were collected with clear plastic tube corers of $5.4 \mathrm{~cm}$ inner diameter to a depth of $10 \mathrm{~cm}$. In the case of the box or multiple corer sampling, sub-sampling was performed $(\varnothing 5.4 \mathrm{~cm})$. As soon as the cores were retrieved, in order to avoid loss of epibenthic specimens which might have been suspended into the water column, the overlying water was filtered through a $32 \mu \mathrm{m}$ mesh size sieve and the material retained on the sieve was backwashed into the plastic container for the $0-1 \mathrm{~cm}$ slice. All sediment cores were then cut into $1 \mathrm{~cm}$ thick horizontal slices to a depth of $5 \mathrm{~cm}$. Prior to fixation with $4 \%$ buffered formalin, samples were placed in a $6 \% \mathrm{MgCl}_{2}$ solution for approximately $15 \mathrm{~min}$ to promote tissue relaxation. Metazoan meiofaunal organisms were extracted from the residue by floatation with Ludox (1.15 specific gravity) and stained with Rose Bengal. Organisms were sorted and identified to their major taxonomic level under a stereoscopic microscope. At least 100 nematodes from the top sediment section and, depending on their relative abundance, 10 to 60 nematodes from each of the remaining sections were randomly picked out, mounted on glycerine slides using a formalin-ethanol-glycerol technique to prevent dehydration, and identified to species level. Nematode classification was based on the pictorial keys of Platt and Warwick (1983, 1988) and Warwick et al. (1998) as well as relevant literature dealing with genera and species from the Mediterranean Sea. The same specimens used for identifications 
were also used for the determination of nematode biomass. Nematode wet weight (WW) was calculated following Andrassy's formula: biomass $(\mu \mathrm{g} \mathrm{WW})=L \times W^{2} / 1600000$; where $L$ is nematode length and $W$ is nematode width (Andrassy, 1956). Dry weight (DW) was assumed to be $25 \%$ of WW (Wieser, 1960). All biomass values reported here are in $\mu \mathrm{g}$ DW; length and width are expressed in $\mu \mathrm{m}$.

\subsection{Data analysis}

Differences in faunal parameters were assessed by one-way or two-way analyses of variance (ANOVA), followed by pairwise comparisons based on the Tukey Honestly Significant Difference test (Tukey HSD). When necessary, data were first $\log (x+1)$ transformed and Bartlett's test was used to check the assumption of homoscedasticity.

Nematode diversity was calculated and expressed as Hill numbers of the orders $N_{0}, N_{1}, N_{2}$ and $N_{\infty}$ (Hill, 1973), as recommended by Heip et al. (1988). These indices differ in their tendency to give different weight to the less common species. The impact of dominance increases and the influence of species richness decreases with increasing order of the diversity number. In addition, two levels of differentiation diversity were measured using the Jaccard dissimilarity index: (1) beta diversity, the change of diversity within and between microhabitats for each mud volcano, and (2) delta diversity, the change of diversity between mud volcanoes.

Non-metric multidimensional scaling (nMDS) ordination was based on Bray-Curtis similarity on square-root transformed abundances. Spearman's rank correlation coefficient was used to assess the relationships between meiofaunal and environmental parameters. The relationships between multivariate nematode community structure and environmental variables were examined using the BIOENV procedure (Clarke and Ainsworth, 1993).

All analyses and graphs were performed using R (R Core Team, 2013) with the exception of Jaccard dissimilarity, the nMDS graph and BIOENV for which Primer v. 6.1.3 (Clarke and Gorley, 2006) was used.

\section{Results}

\subsection{Standing stocks}

An overview of the meiofaunal taxa composition and densities for the different microhabitats of the Amsterdam and Napoli mud volcanoes is given in Table 2. Altogether, 23 metazoan meiofaunal groups were found, with the highest number being recorded at the Pcc microhabitat of Amsterdam (16 taxa) and the lowest at the Lam microhabitat of Napoli ( 8 taxa). Taxa that were not encountered at the Pfar site but were found in the other microhabitats included kinorhynchs, cumaceans, gastrotrichs, halacaroids and some temporary meiofauna such as bivalves, gastropods and amphipods (Table S1). The same taxa were also missing from

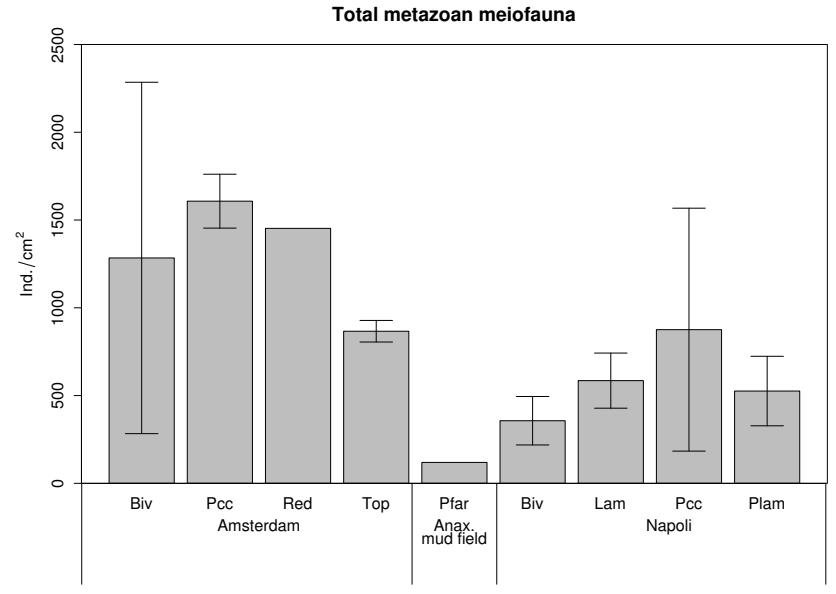

Fig. 2. Total metazoan meiofauna (individuals per $10 \mathrm{~cm}^{2}$ ) per microhabitat (Biv: bivalve shells; Pcc: periphery of carbonate crusts; Red: reduced sediments; Top: summit of the mud volcano; Lam: Lamellibrachia microhabitat; Plam: periphery of Lamellibrachia; Pfar: far periphery).

the Lam microhabitat of Napoli, but generally there was no common pattern of how the rare taxa where distributed among the microhabitats.

Meiofauna was dominated by nematodes, which ranged from 82.4 to $95.7 \%$ (Table 2: Biv at Amsterdam and Lam at Napoli respectively). They were followed by harpacticoid copepods which, together with their nauplii, ranged from 2.6 to $10.8 \%$ (Table 2: Lam at Napoli and Top at Amsterdam, respectively). Other taxa with significant contributions were annelids (including Polychaeta, Oligochaeta and Annelida "Incertae sedis"), ranging from 0.8 to $2.1 \%$ (Table 2: at Amsterdam Red and Biv, respectively), and molluscs ranging from 0.1 to $2.9 \%$ (Table 2: Napoli Lam and Plam for the smallest and Amsterdam Biv for the largest abundance). All other taxa, including both permanent and temporal meiofauna, contributed less than $1 \%$ (Table 2). The highest meiofauna densities (Fig. 2) were recorded at the Biv microhabitat of Amsterdam (1992 ind. per $10 \mathrm{~cm}^{2}$ ) and the lowest at the Pfar microhabitat (119ind. per $10 \mathrm{~cm}^{2}$ ). Average densities for Amsterdam and Napoli were $1281 \pm 519$ and $586 \pm 329$ ind. per $10 \mathrm{~cm}^{2}$, respectively. Nematode densities followed the same pattern, with the highest values occurring at the Biv microhabitat of Amsterdam (1835 ind per $10 \mathrm{~cm}^{2}$ ) and the lowest at the Pfar site $\left(108\right.$ ind per $\left.10 \mathrm{~cm}^{2}\right)$. Average values were $1152 \pm 528$ and $535 \pm 295$ ind. per $10 \mathrm{~cm}^{2}$ for Amsterdam and Napoli, respectively (Fig. 3). Two-way ANOVA with "area" and "microhabitat type" as main factors showed a significant "area" effect for both meiofaunal and nematode densities, with Amsterdam differing from the Pfar site in both cases and from Napoli for meiofauna (Table S2, Tukey HSD: $P<0.05)$. 
Table 2. Meiofauna relative abundance $(\%)$ and density (individuals per $10 \mathrm{~cm}^{2} \pm \mathrm{SD}$ ) at the different microhabitats $(n=1$ for Red and Pfar). For a list of taxa included in "Others" see Table S1 (Biv: bivalve shells; Pcc: periphery of carbonate crusts; Red: reduced sediments; Top: summit of the mud volcano; Lam: Lamellibrachia microhabitat; Plam: periphery of Lamellibrachia; Pfar: far periphery).

\begin{tabular}{clrrrrr}
\hline \multicolumn{1}{l}{ Area } & Habitat type & Nematoda & Copepoda & Annelida & Mollusca & Others \\
\hline Abundance (\%) & & & & & & \\
Amsterdam & Biv & 82.4 & 5.4 & 2.1 & 2.9 & 7.3 \\
& Pcc & 92.6 & 3.4 & 1.7 & 0.4 & 1.9 \\
& Red & 93.4 & 4.5 & 0.8 & 0.7 & 0.6 \\
& Top & 84.6 & 10.8 & 1.9 & 0.5 & 2.2 \\
Napoli & Biv & 88.1 & 8.0 & 1.9 & 0.0 & 1.9 \\
& Lam & 95.7 & 2.6 & 1.0 & 0.1 & 0.6 \\
& Pcc & 89.9 & 6.1 & 1.3 & 0.2 & 2.6 \\
& Plam & 89.3 & 7.6 & 1.4 & 0.1 & 1.6 \\
Anax. mud field & Pfar & 90.7 & 4.9 & 1.7 & 0.6 & 2.1 \\
\hline \multirow{2}{*}{ Density (ind/10cm $\left.{ }^{2}\right)$} & & & & & & \\
Amsterdam & Biv & $1127( \pm 1002)$ & $57( \pm 23)$ & $33( \pm 37)$ & $19( \pm 17)$ & $48( \pm 44)$ \\
& Pcc & $1490( \pm 186)$ & $54( \pm 3)$ & $27( \pm 12)$ & $7( \pm 3)$ & $29( \pm 20)$ \\
& Red & 1357 & 65 & 12 & 10 & 9 \\
& Top & $735( \pm 108)$ & $91( \pm 48)$ & $16( \pm 1)$ & $4( \pm 6)$ & $19( \pm 8)$ \\
Napoli & Biv & $313( \pm 116)$ & $29( \pm 15)$ & $8( \pm 6)$ & $0( \pm 0)$ & $6( \pm 0)$ \\
& Lam & $560( \pm 150)$ & $16( \pm 10)$ & $6( \pm 2)$ & $0( \pm 1)$ & $3( \pm 2)$ \\
& Pcc & $780( \pm 605)$ & $58( \pm 55)$ & $10( \pm 7)$ & $2( \pm 2)$ & $24( \pm 23)$ \\
& Plam & $476( \pm 212)$ & $33( \pm 19)$ & $6( \pm 3)$ & $1( \pm 1)$ & $9( \pm 8)$ \\
Anax. mud field & Pfar & 108 & 5 & 2 & 1 & 3 \\
\hline
\end{tabular}

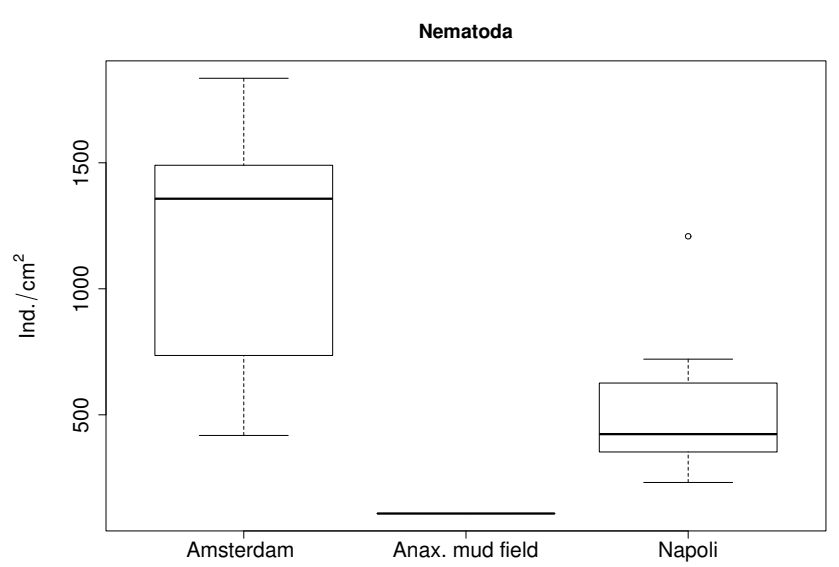

Fig. 3. Box-plot showing differences in nematode densities between the Amsterdam and Napoli mud volcanoes and the far periphery site (Anaximander mud field).

Most meiofauna was found on the top layer of the sediment $(0-1 \mathrm{~cm})$ and the same pattern was also followed by nematodes, the dominant group (Fig. 4).

The Spearman rank correlation analysis revealed very few significant relationships. Nematodes (i.e. nematode abundance, nematode species densities and nematode diversity) significantly correlated with proxies of food availability (organic carbon, lipids, carbohydrates and bio-available OM; see Table 3), while the other abundant meiofauna taxa (cope- pods, annelids and molluscs) and total meiofauna correlated only with oxygen, the only exception being molluscs and total meiofauna which correlated also with methane (Table 3).

\subsection{Nematode communities}

In total, more than 4000 nematodes were identified, belonging to 27 families, 83 genera and 143 species. The genera that contributed, on average, with more than $1 \%$ to the total abundance are listed in Table 4. From the total number of species identified, only three of them, one belonging to the genus Aponema and two belonging to the genus Leptolaimus, were present at all microhabitats, whereas 29 species $(20.3 \%)$ or 14 genera $(16.9 \%)$ were present at only one microhabitat. Among the two most abundant genera, Aponema was represented by a single species (average relative abundance: $15.4 \%$ ) while the genus Sabatieria was represented by a complex of three species (Sabatieria sp.1, Sabatieria sp.3 and Sabatieria sp.4). However, only two of them, one belonging to the Pulchra group (Sabatieria sp.4) and the other to the Celtica group (Sabatieria sp.1), were found in relatively high numbers (on average $14.5 \%$ and $6.3 \%$, respectively). Out of the 143 species, 18 were singletons $(12.6 \%)$ and 14 were doubletons (9.8\%). Aponema sp. 1 and Sabatieria sp. 4, were the most abundant species comprising, on average, $15.4 \%$ and $14.5 \%$, respectively, of the community. At some microhabitats, they strongly dominated the community. For example, at the Red microhabitat, 

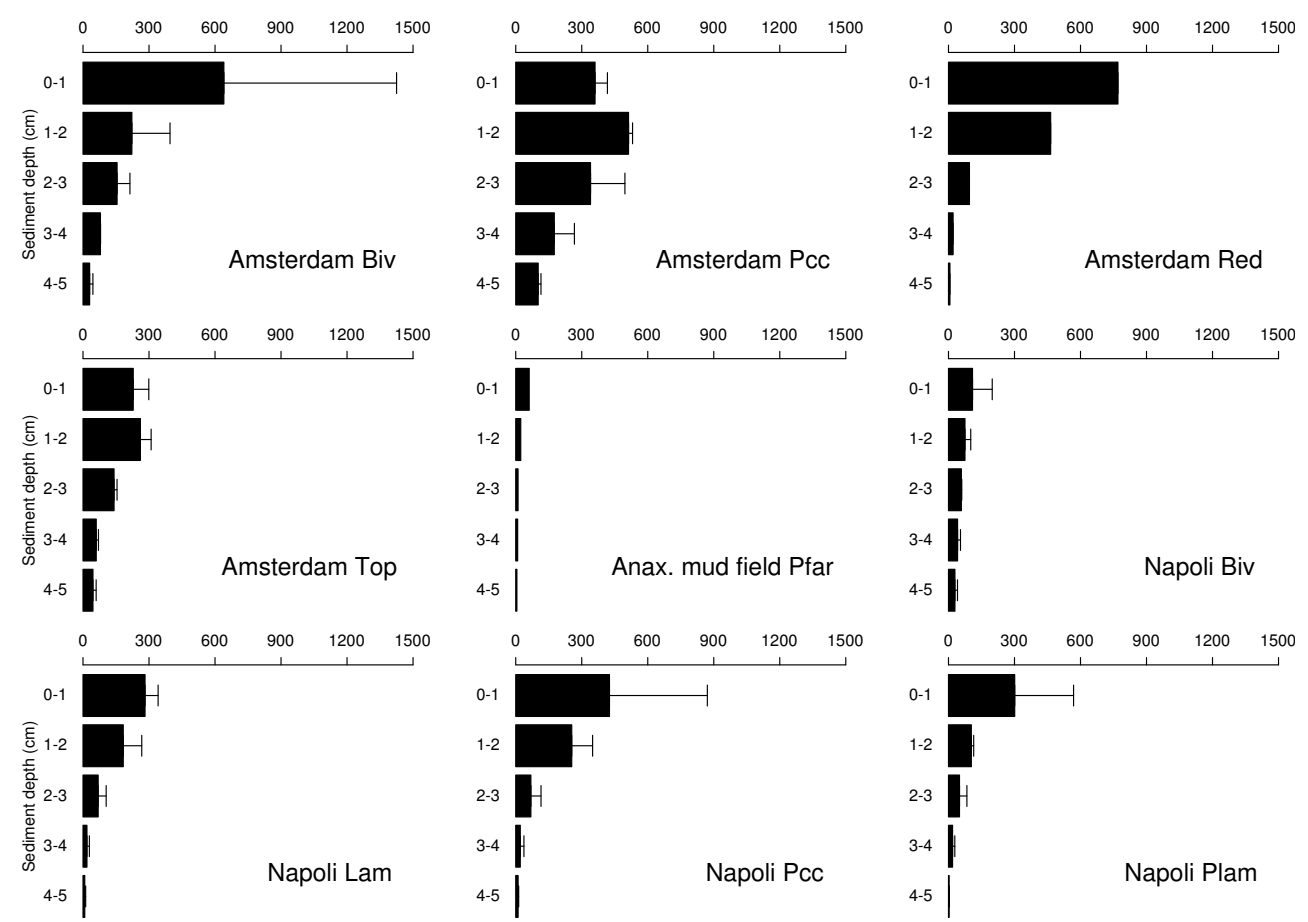

Fig. 4. Vertical distribution (individuals per $10 \mathrm{~cm}^{2}$ ) of nematodes for the different microhabitats (Biv: bivalve shells; Pcc: periphery of carbonate crusts; Red: reduced sediments; Top: summit of the mud volcano; Lam: Lamellibrachia microhabitat; Plam: periphery of Lamellibrachia; Pfar: far periphery).

Table 3. Spearman's correlation coefficient between environmental variables (published by Ritt et al., 2012), meiofaunal taxa, nematode species and nematode diversity (Hill's numbers). Abbreviations: total nitrogen (TN); molar ratio (C:N); total lipids (Lipids); total carbohydrates $(\mathrm{CarbH})$; total hydrolysable amino acids (THAA); proportion of bio-available OM (Bio-av. OM); percentages of carbonates (Carbonate).

\begin{tabular}{|c|c|c|c|c|c|c|c|c|c|c|c|c|c|}
\hline & $\mathrm{pH}$ & {$\left[\mathrm{O}_{2}\right]$} & {$\left[\mathrm{CH}_{4}\right]$} & {$\left[\mathrm{SO}_{4}{ }^{2}-\right]$} & {$\left[\mathrm{Cl}^{-}\right]$} & Organic C & $\mathrm{TN}$ & C:N & Lipids & $\mathrm{CarbH}$ & THAA & Bio-av. OM & Carbonate \\
\hline Nematoda & 0.05 & -0.47 & 0.46 & -0.05 & 0.24 & $0.73^{*}$ & 0.66 & -0.46 & $0.90^{*}$ & 0.60 & 1.00 & $0.90^{*}$ & -0.80 \\
\hline Copepoda & 0.06 & $-0.56^{*}$ & 0.29 & -0.12 & 0.21 & -0.08 & -0.54 & 0.64 & -0.50 & -1.00 & -0.60 & -0.80 & -0.40 \\
\hline Annelida & 0.08 & $-0.75^{* *}$ & 0.33 & -0.25 & 0.15 & -0.07 & -0.61 & 0.63 & -0.82 & -0.46 & -0.56 & -0.46 & -0.40 \\
\hline Mollusca & 0.34 & $-0.63^{*}$ & $0.55^{*}$ & -0.26 & 0.1 & 0.21 & -0.26 & 0.36 & -0.15 & -0.87 & -0.41 & -0.67 & -0.20 \\
\hline Total meiofauna & 0.08 & $-0.54^{*}$ & $0.56^{*}$ & 15 & 0.20 & 0.59 & 0.03 & 0.23 & 0.30 & -0.30 & 0.50 & 0.30 & -0.80 \\
\hline Aponema sp.1 & 0.20 & -0.37 & 0.38 & -0.02 & 0.24 & $0.78^{* *}$ & 0.54 & -0.64 & 0.70 & 0.30 & 0.60 & 0.30 & 0.40 \\
\hline Sabatieria sp.4 & -0.05 & 0.02 & 0.32 & 0.10 & 0.10 & $0.69^{*}$ & 0.70 & -0.59 & 0.67 & 0.87 & 0.87 & $0.97^{* *}$ & -0.26 \\
\hline Sabatieria sp.1 & 0.16 & $-0.63^{*}$ & 0.19 & -0.19 & 0.31 & -0.09 & -0.88 & $0.89^{*}$ & -0.78 & $-0.89^{*}$ & -0.78 & -0.78 & -0.40 \\
\hline Molgolaimus sp & -0.30 & 0.05 & 0.05 & & -0.38 & $-0.68^{*}$ & -0.58 & 0.80 & -0.41 & -0.62 & -0.15 & -0.15 & -0.63 \\
\hline Manganonema sp.2 & -0.07 & 0.2 & $-0.58^{*}$ & 5 & -0.29 & -0.56 & -0.13 & 0.00 & na & na & na & na & 0.77 \\
\hline$N_{0}$ & 0.01 & -0.03 & -0.27 & -0.07 & -0.05 & $-0.90^{* * *}$ & -0.71 & 0.69 & -0.87 & -0.67 & -0.87 & -0.72 & 0.11 \\
\hline$N_{1}$ & 0.03 & -0.02 & -0.27 & -0.05 & -0.05 & $-0.79^{* *}$ & -0.54 & 0.46 & -0.60 & $-0.90^{*}$ & -0.80 & $-0.90^{*}$ & 0.40 \\
\hline$N_{2}$ & 0.06 & 0.03 & -0.28 & -0.08 & -0.09 & $-0.75^{* *}$ & -0.54 & 0.46 & -0.60 & $-0.90^{*}$ & -0.80 & $-0.90^{*}$ & 0.40 \\
\hline$N_{\text {inf }}$ & 0.25 & 0.15 & -0.29 & -0.09 & -0.03 & $-0.76^{* *}$ & -0.60 & 0.61 & -0.60 & $-0.90^{*}$ & -0.80 & $-0.90^{*}$ & -0.20 \\
\hline
\end{tabular}

${ }^{*} P<0.05,{ }^{* *} P<0.01,{ }^{* * *} P<0.001$, na: not available

they accounted for $92.6 \%$ of the community (Aponema sp. 1: $56.6 \%$; Sabatieria sp. 4: 36.0\%). Similarly, Sabatieria sp. 4 dominated the community at the Lam microhabitat of Napoli with $42.8 \%$. Surprisingly, Aponema was also the most abundant genus at the Pfar microhabitat (Table 4, $13.8 \%$ ), while Thalassomonhystera, Manganonema and Acantholaimus were ranked 2nd to 4th with $11.6 \%$, $5.5 \%$ and $5.0 \%$, respectively (Table 4 ).
When comparing the genus composition of the two mud volcanoes, they both exhibited the same pattern of dominance, with Sabatieria, Aponema and Metalinhomoeus being the three most abundant genera together comprising $56.6 \%$ and $35.1 \%$ of the abundance for Amsterdam and Napoli, respectively. However, when they were compared in terms of species composition, they showed obvious differences. For example, for Amsterdam, the four most abundant species 
Table 4. Relative abundance of nematode genera contributing, on average, with more than $1 \%$ to the total abundance (Biv: bivalve shells; Pcc: periphery of carbonate crusts; Red: reduced sediments; Top: summit of the mud volcano; Lam: Lamellibrachia microhabitat; Plam: periphery of Lamellibrachia; Pfar: far periphery).

\begin{tabular}{|c|c|c|c|c|c|c|c|c|c|}
\hline \multirow[b]{2}{*}{ Genus } & \multicolumn{4}{|c|}{ Amsterdam } & \multicolumn{4}{|c|}{ Napoli } & \multirow{2}{*}{$\begin{array}{l}\text { Anax } \\
\text { mud field } \\
\text { Pfar }\end{array}$} \\
\hline & Biv & Pcc & Red & Top & Biv & Lam & Pcc & Plam & \\
\hline Sabatieria & 27.0 & 22.3 & 36.0 & 17.4 & 2.0 & 48.3 & 17.0 & 16.4 & 1.6 \\
\hline Aponema & 23.6 & 11.4 & 56.6 & 3.6 & 9.9 & 10.6 & 14.1 & 3.9 & 13.8 \\
\hline Metalinhomoeus & 4.8 & 11.9 & 3.6 & 8.4 & 5.2 & 8.9 & 2.5 & 1.8 & 0.0 \\
\hline Daptonema & 1.0 & 1.8 & 0.0 & 5.1 & 3.2 & 13.9 & 1.0 & 3.5 & 1.9 \\
\hline Thalassomonhystera & 2.0 & 1.7 & 0.0 & 4.2 & 2.5 & 0.0 & 3.0 & 4.6 & 11.6 \\
\hline Leptolaimus & 4.7 & 1.1 & 2.0 & 7.9 & 3.3 & 1.5 & 2.0 & 2.1 & 4.2 \\
\hline Setosabatieria & 0.0 & 0.0 & 0.0 & 0.0 & 0.0 & 0.0 & 12.9 & 14.9 & 0.0 \\
\hline Molgolaimus & 0.5 & 4.3 & 0.0 & 4.3 & 4.6 & 0.8 & 5.9 & 4.2 & 0.0 \\
\hline Syringolaimus & 1.2 & 0.0 & 0.0 & 2.1 & 9.4 & 0.5 & 1.5 & 1.9 & 3.2 \\
\hline Desmodora & 1.4 & 4.8 & 0.0 & 0.0 & 3.2 & 1.0 & 5.9 & 3.3 & 0.0 \\
\hline Anticoma & 2.5 & 7.7 & 0.0 & 6.3 & 0.4 & 0.0 & 0.6 & 0.6 & 0.5 \\
\hline Microlaimus & 2.6 & 2.5 & 0.0 & 2.7 & 2.3 & 0.4 & 3.1 & 1.8 & 1.4 \\
\hline Acantholaimus & 0.6 & 0.5 & 0.0 & 1.9 & 4.9 & 0.2 & 0.5 & 2.2 & 5.0 \\
\hline Marylynnia & 0.0 & 0.0 & 0.0 & 0.0 & 10.8 & 0.0 & 3.0 & 1.1 & 0.0 \\
\hline Paramonhystera & 0.7 & 1.1 & 0.0 & 2.2 & 1.4 & 7.1 & 0.2 & 1.0 & 1.3 \\
\hline Laimella & 0.0 & 3.5 & 0.0 & 0.3 & 6.7 & 0.0 & 0.0 & 2.1 & 0.0 \\
\hline Sphaerolaimus & 7.1 & 1.1 & 0.0 & 0.0 & 0.1 & 0.0 & 0.1 & 1.1 & 2.1 \\
\hline Halalaimus & 1.5 & 1.1 & 0.0 & 0.3 & 1.3 & 0.0 & 0.9 & 1.6 & 4.2 \\
\hline Viscosia & 2.1 & 2.8 & 0.5 & 2.2 & 1.3 & 0.0 & 0.9 & 0.5 & 0.5 \\
\hline Manganonema & 0.0 & 0.0 & 0.0 & 2.0 & 2.1 & 0.0 & 0.0 & 0.8 & 5.5 \\
\hline Pareudesmoscolex & 0.5 & 2.6 & 0.0 & 1.5 & 0.5 & 0.0 & 4.8 & 0.4 & 0.0 \\
\hline Tricoma & 1.8 & 1.4 & 0.0 & 1.0 & 0.3 & 0.0 & 1.3 & 1.4 & 1.6 \\
\hline Pierrickia & 1.3 & 4.3 & 0.0 & 2.1 & 0.6 & 0.0 & 0.0 & 0.4 & 0.0 \\
\hline
\end{tabular}

were Aponema sp.1 (22.9\%), Sabatieria sp.4 (13.0\%), Sabatieria sp.1 (12.7\%) and Metalinhomoeus sp.1 (5.4\%). On the other hand, Napoli was dominated by Sabatieria sp.4 (19.7\%), Aponema sp.1 (8.3\%), Setosabatieria sp.1 (5.8\%) and Daptonema sp.3 (5.3\%). These differences in composition were confirmed by the nMDS analysis based on species composition (Fig. 5), which showed a clear separation between the Amsterdam and Napoli mud volcanoes (ANOSIM: $R=0.29 ; P=0.035)$. The BIOENV procedure showed that organic carbon was the variable that best explained the structure and composition of nematode assemblages $(R=0.809)$.

\subsection{Diversity patterns}

The highest number of species $\left(N_{0}=66\right)$ was recorded in a sample collected from the Plam microhabitat of Napoli and the lowest in a sample collected from the Red microhabitat of Amsterdam $\left(N_{0}=12\right)$. In general, species richness $\left(N_{0}\right)$ was highest at the Plam and Biv microhabitats of Napoli and lowest at the Red and Lam microhabitats of Napoli (Table 5). The Pfar site displayed equally high species richness with the two most diverse microhabitats of Napoli (Biv and Plam microhabitat). This pattern was retained for all Hill's numbers though the Pfar microhabitat always showed higher val-

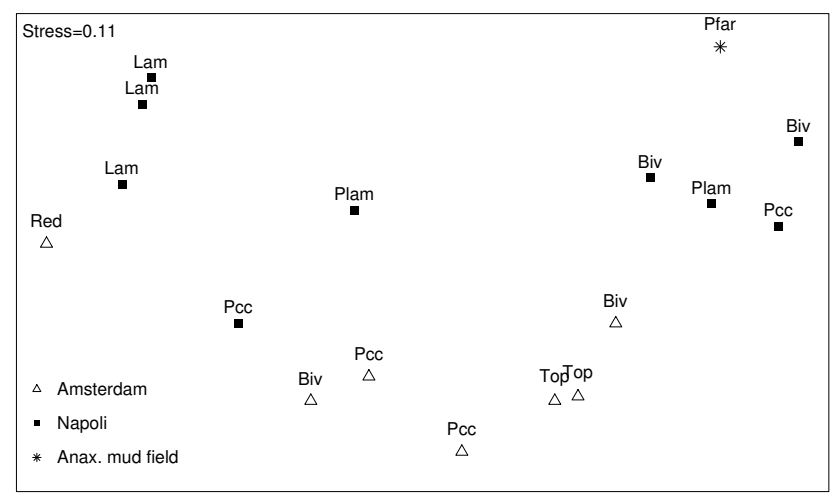

Fig. 5. Non-metric multidimensional scaling (nMDS) based on Bray-Curtis similarity of square root transformed nematode species data (Biv: bivalve shells; Pcc: periphery of carbonate crusts; Red: reduced sediments; Top: summit of the mud volcano; Lam: Lamellibrachia microhabitat; Plam: periphery of Lamellibrachia; Pfar: far periphery).

ues (Table 5). Beta diversity (Table 6) indicated that there was a high within-microhabitat dissimilarity, i.e. between replicates of the same microhabitat (Table 6, Within microhabitats: all but one value $>0.50$ ). Between microhabitats, 

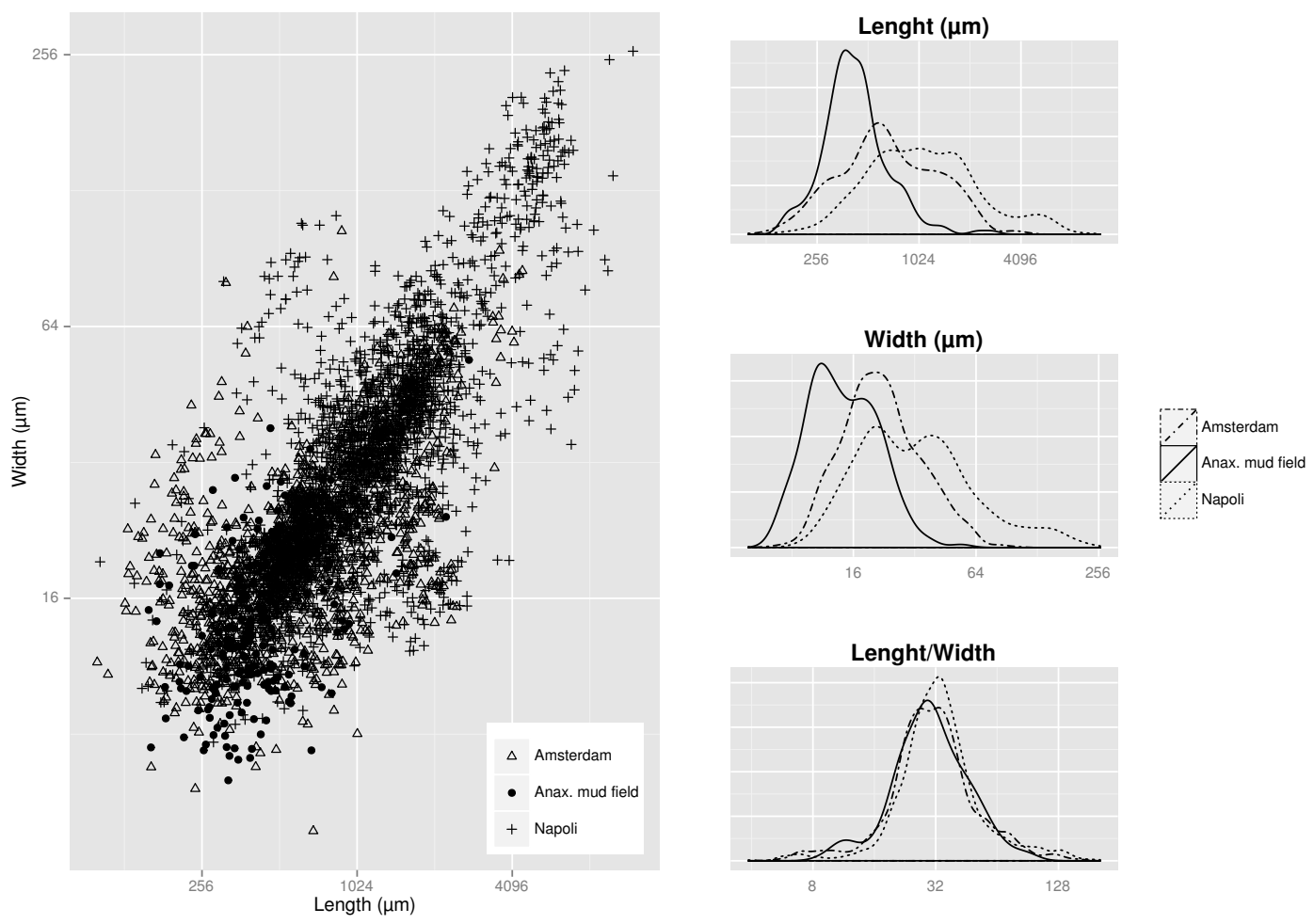

Fig. 6. Morphometric data of individual nematodes. Large panel (left) shows length-width relationship at the three sampling sites. Smaller panels (right) show frequency distributions of length, width, and length : width ratio.

highest dissimilarity was observed between Red and all other microhabitats for Amsterdam (Table 6, 0.80-0.86), and between Lam and all other microhabitats for Napoli (Table 6, 0.67-0.72). High dissimilarity was also observed between all microhabitats and the Pfar site. On the other hand, when comparing similar microhabitats between the two mud volcanoes, dissimilarity ranged within moderate values (Table 6: $\delta$-diversity, 0.35-0.52).

\subsection{Morphometrics and biomass}

The analysis of morphometric data showed that, on average, nematodes from cold-seep areas were much larger compared to those from the Pfar microhabitat (Table 7). For example, the average nematode dry weight for Amsterdam, Napoli and the Pfar microhabitat was $0.17,1.83$ and $0.03 \mu \mathrm{g}$, respectively. This large difference was due to two factors: a shift in the size spectra of seep nematodes towards longer and wider animals (Fig. 6: length and width panels), and the occurrence of a relatively high number of large nematodes (length $>4000 \mu \mathrm{m}$ ) at Napoli (Fig. 6); the largest nematode at the Pfar site had a length of only $2782 \mu \mathrm{m}$. This shift in the nematode size spectra, in conjunction with the density differences found between Amsterdam, Napoli and the Pfar site, resulted in very large biomass differences. Thus, the average total biomass at each site was 202.29, 1228.73 and $3.13 \mu \mathrm{g}$ per $10 \mathrm{~cm}^{2}$ for Amsterdam, Napoli and the Pfar site, respectively.

\section{Discussion}

\subsection{Mud volcanoes in the eastern Mediterranean}

The two mud volcanoes, although very different in shape and size, share a very similar external morphology with a central mound and a moat surrounding it. This structure is commonly found in many other mud volcanoes along the European active and passive margins (e.g. Lykousis et al., 2009, and references therein) and is probably among the most common features in the Mediterranean Ridge Mud Diapiric Belt (Dimitrov, 2002). This structural formation is probably caused by a collapse of the sea floor after the eruption of mud from a depth of 1 to $2 \mathrm{~km}$ below the mud volcano, indicating that subsidence and tectonics play an important role in the formation of these depressions (Zitter et al., 2005). Apart from their external morphology, the two mud volcanoes also appear to share similar microhabitats, mainly areas with the siboglinid polychaete Lamellibrachia anaximandri, the lucinid Lucinoma kazani and the mytilid Idas modiolaeformis (Olu-Le Roy et al., 2004; Ritt et al., 2012). However, despite their visual similarities, these microhabitats have inherent differences in terms of sediment 
Table 5. Diversity indices (Hill numbers) of nematode communities from different microhabitats (Biv: bivalve shells; Pcc: periphery of carbonate crusts; Red: reduced sediments; Top: summit of the mud volcano; Lam: Lamellibrachia microhabitat; Plam: periphery of Lamellibrachia; Pfar: far periphery).

\begin{tabular}{llrrrr}
\hline Area & Habitat type & $N_{0}$ & $N_{1}$ & $N_{2}$ & $N_{\text {inf }}$ \\
\hline Amsterdam & Biv & $43( \pm 18)$ & $20.1( \pm 14.7)$ & $13.0( \pm 10.9)$ & $6.3( \pm 4.5)$ \\
& Pcc & $45( \pm 4)$ & $18.1( \pm 6.2)$ & $9.8( \pm 2.2)$ & $4.4( \pm 0.5)$ \\
& Red & 12 & 2.8 & 2.2 & 1.8 \\
\multirow{2}{*}{ Napoli } & Top & $46( \pm 7)$ & $23.7( \pm 9.8)$ & $14.6( \pm 8.1)$ & $5.6( \pm 2.8)$ \\
& Biv & $56( \pm 1)$ & $28.8( \pm 1.8)$ & $18.4( \pm 2.3)$ & $7.1( \pm 0.9)$ \\
& Lam & $15( \pm 2)$ & $4.5( \pm 2.0)$ & $3.3( \pm 1.8)$ & $2.5( \pm 1.6)$ \\
\multirow{2}{*}{ Anax. mud field } & Pcc & $48( \pm 24)$ & $23.5( \pm 14.8)$ & $13.7( \pm 7.9)$ & $5.4( \pm 1.3)$ \\
& Plam & $53( \pm 19)$ & $29.7( \pm 15.2)$ & $17.8( \pm 7.6)$ & $6.1( \pm 0.4)$ \\
& Pfar & 56 & 36.7 & 23.8 & 7.3 \\
\hline
\end{tabular}

Table 6. Beta and delta diversity based on Jaccard dissimilarity. Dissimilarity increases from 0 to 1 (Biv: bivalve shells; Pcc: periphery of carbonate crusts; Red: reduced sediments; Top: summit of the mud volcano; Lam: Lamellibrachia microhabitat; Plam: periphery of Lamellibrachia; Pfar: far periphery).

\begin{tabular}{|c|c|c|c|c|c|c|c|c|}
\hline & Microhabitat & Biv & Lam & Plam & Pcc & Red & Top & All habitats \\
\hline & & \multicolumn{3}{|c|}{$\beta$-diversity } & & & & \\
\hline \multicolumn{9}{|l|}{ Within habitats } \\
\hline Amsterdam & & 0.63 & & & 0.51 & & 0.52 & \\
\hline Napoli & & 0.44 & 0.54 & 0.56 & 0.69 & & & \\
\hline \multicolumn{9}{|l|}{ Between habitats } \\
\hline \multicolumn{9}{|l|}{ Amsterdam } \\
\hline & Pcc & 0.39 & & & & & & \\
\hline & Red & 0.82 & & & 0.86 & & & \\
\hline & Top & 0.45 & & & 0.43 & 0.80 & & \\
\hline & Pfar & 0.49 & & & 0.61 & 0.80 & 0.50 & 0.46 \\
\hline \multicolumn{9}{|l|}{ Napoli } \\
\hline & Lam & 0.71 & & & & & & \\
\hline & Plam & 0.41 & 0.67 & & & & & \\
\hline & Pcc & 0.46 & 0.72 & 0.45 & & & & \\
\hline & Pfar & 0.49 & 0.69 & 0.57 & 0.55 & & & 0.54 \\
\hline \multicolumn{9}{|c|}{$\delta$-diversity } \\
\hline Between volcanoes & & 0.47 & & & 0.52 & & & 0.35 \\
\hline
\end{tabular}

chemistry and macrofaunal composition (Ritt et al., 2012). Amsterdam is characterized by the presence of gas hydrates (Lykousis et al., 2009), while brines are abundant on Napoli (Charlou et al., 2003). In addition, Amsterdam appears to be more active, based on the higher sediment temperature (J. P. Foucher, personal communication, 2012) and methane concentration (Charlou et al., 2003). These differences are reflected in the distribution of macrofaunal communities, with Napoli having an overall higher taxonomic diversity and the reduced sediments of Amsterdam being mainly colonized by symbiont-bearing vesicomyid bivalves and heterotrophic dorvilleid polychaetes (Ritt et al., 2012).

\subsection{Meiobenthos from seep and non-seep areas}

Data from Pfar, the most remote from the seep influence microhabitat, are in line with previous research in the area, indicating that meiofaunal densities and biomass at bathyal and abyssal sediments of the eastern Mediterranean are among the lowest worldwide (Tselepides and Lampadariou, 2004; Lampadariou et al., 2009; Gambi et al., 2010). This pattern has been mainly related to the highly oligotrophic conditions of the eastern Mediterranean and a depletion of food with increasing water depth (Danovaro et al., 2000; Tselepides et al., 2004; Lampadariou and Tselepides, 2006). In contrast, the seep conditions appear to favour meiofaunal communities since both mud volcanoes showed significantly higher standing stocks when compared with the far peripheral site. 
Table 7. Nematode morphometrics and biomass values.

\begin{tabular}{llrrrrr}
\hline Area & Measurement & Arithmetic mean & SD & Geometric mean & Max & Min \\
\hline \multirow{2}{*}{ Amsterdam } & Length $(\mu \mathrm{m})$ & 831.31 & 586.20 & 668.35 & 4484.57 & 100.40 \\
& Width $(\mu \mathrm{m})$ & 24.26 & 11.91 & 21.90 & 104.14 & 4.88 \\
& Biomass $(\mu \mathrm{g} \mathrm{DW})$ & 0.15 & 0.34 & 0.05 & 5.08 & $<0.01$ \\
\multirow{2}{*}{ Napoli } & Length $(\mu \mathrm{m})$ & 1461.38 & 1345.96 & 1083.88 & 12051.54 & 102.99 \\
& Width $(\mu \mathrm{m})$ & 41.30 & 34.47 & 32.58 & 260.61 & 7.68 \\
& Biomass $(\mu \mathrm{g} \mathrm{DW})$ & 1.62 & 5.99 & 0.18 & 127.89 & $<0.01$ \\
Anaximander & Length $(\mu \mathrm{m})$ & 478.82 & 290.94 & 428.32 & 2781.52 & 158.98 \\
mud field & Width $(\mu \mathrm{m})$ & 15.39 & 6.58 & 14.23 & 53.97 & 6.32 \\
& Biomass $(\mu \mathrm{g} \mathrm{DW})$ & 0.03 & 0.09 & 0.01 & 1.27 & $<0.01$ \\
\hline
\end{tabular}

It should be noted, however, that due to sampling time restrictions, only one sample could be obtained from the far periphery. Thus, taking also into account the high environmental variability of deep-sea sediments and the generally patchy distribution of meiofauna (Coull and Bell, 1979; Findlay, 1981), any conclusions regarding the far periphery should be considered with caution.

The high variability observed between replicate samples at the Biv microhabitat of Amsterdam and the Pcc microhabitat of Napoli, a feature inherent to meiofauna in general (Findlay, 1981), is indicative of the high spatial variability of fluid intensity and the microdistribution of chemicals (methane, oxygen, sulphate and chloride) at the two mud volcanoes (Ritt et al., 2012). Despite the much higher methane concentration (Charlou et al., 2003), and the opposite trends found in the methane and oxygen gradients at the two mud volcanoes (Ritt et al., 2012), our results show that food availability and quality are the main driving factors for the observed spatial distribution of nematodes. This is clearly shown by the significant positive correlations between the various nematode parameters (i.e. nematode abundance, nematode species densities and nematode diversity) and the concentration of organic carbon and food quality proxies (e.g. lipids, carbohydrates and bio-available OM, Ritt et al., 2012). The multivariate analysis also indicated food as the main driving factor, because the sole variable that best matched the observed nematode assemblage pattern was organic carbon. The above results, together with the much higher meiofaunal abundance found at the two mud volcanoes suggest that, if the effects of fluid emissions are not lethal, then nematodes can benefit from the increased bacterial production at seeps by increasing their numbers and by developing a specialised fauna (Vanreusel et al., 2010a). The strong negative correlation between other meiofaunal taxa (i.e. copepods, annelids, molluscs and total meiofauna) and oxygen concentration at the sediment-water interface, although not providing a direct indication of oxygen availability within the interstitial space, confirms previous studies which suggest that besides food, oxygen is also an important factor structuring the spatial distribution of meiofauna (e.g. Neira et al., 2001; Sergeeva and Gulin, 2007; Sellanes et al., 2010).
The vertical distribution of nematodes showed a typical pattern with gradually decreasing densities at deeper layers (Shirayama, 1984; Danovaro et al., 1995). However, while below $5 \mathrm{~cm}$ depth, no more individuals were found at the far peripheral site sample; nematodes were found to thrive even below that sediment depth at the two mud volcanoes (V. Kalogeropoulou, personal observation, 2010). This may be an indication of favourable conditions at the two seep areas, although the explanation for this observation is not clear due to the lack of vertical environmental profiles linked with our samples.

The comparison of meiofauna abundance between the two mud volcanoes showed that densities were significantly higher at Amsterdam. A similar pattern was also found for macrofauna by Olu-Le Roy et al. (2004), who compared chemosynthetic communities from six mud volcanoes in the eastern Mediterranean, including Amsterdam and Napoli. In their study, Olu-Le Roy et al. (2004) also reported that Amsterdam had higher values compared to Napoli, a pattern which they attributed to the higher methane fluxes in the former and the greater instability due to the existence of brine areas in the latter. Higher macrofaunal densities were also observed at Amsterdam by Ritt et al. (2012), reaching over 2.3 times that of Napoli. In contrast to the above trends for densities, the trend for nematode biomass was opposite. This time, Napoli displayed increased values which, in fact, were one and two orders of magnitude larger compared to the Pfar site and Amsterdam, respectively. The main reason behind these differences was an apparent shift in nematode size spectra towards longer and wider animals at Napoli. A similar shift in nematode size spectra has also been found in studies from other chemosynthetic environments (e.g. Vanreusel et al., 1997; Soltwedel et al., 2005; Vanreusel et al., 2010a), an adaptation that may be advantageous in thiobiotic conditions, as suggested by Jensen (1987).

The nematode community composition and richness varied strongly between microhabitats, displaying some notable features. The community at the Red sediments of Amsterdam was dominated by two equally abundant species (Aponema sp.1 and Sabatieria sp.4), which together comprised more than $90 \%$ of the faunal abundance. Similarly, the community 
at the Lam microhabitat of Napoli was dominated by only one species (Sabatieria sp.4), which comprised almost $50 \%$. As a consequence of the increased dominance of a few taxa, these two microhabitats displayed very low species richness. The dominance of the genus Sabatieria is not surprising since it is a typical genus of suboxic or anoxic shallow-water muddy sediments, observed to also thrive in reduced deepsea habitats such as the Storegga Siboglinidae habitat in the north Atlantic (Van Gaever et al., 2009b), the Darwin mud volcano seep site in the central Atlantic (Pape et al., 2011) or in the REGAB cold seep of the Gulf of Guinea in the south Atlantic (Van Gaever et al., 2009a).

Surprising, however, are the high numbers of Aponema sp.1, which was dominant not only at the Red microhabitats of Amsterdam but also at the Pfar site, although with a much lower percentage (56.6\% vs. $13.8 \%$ ). Another striking feature of the Pfar site was the fact that the genus Manganonema, a genus that is found only rarely and in very low numbers (Zeppilli et al., 2011b), was ranked third. The above results are unexpected since in the Mediterranean, Thalassomonhystera, Acantholaimus and Halalaimus are usually the dominant genera at bathyal and abyssal depths (Vanreusel et al., 2010b, and references therein), although occasionally other genera such as Syringolaimus, Sphaeorolaimus and Theristus can also gain in importance (Soetaert and Heip, 1995; Lampadariou and Tselepides, 2006; Vanreusel et al., 2010b). The dominance of Aponema and the high numbers of Manganonema at the Pfar site suggest that, despite being $2 \mathrm{nmi}$ away from the mud volcano, this area might still be under its influence, or at least has been in the past, thus providing favourable conditions for opportunistic and tolerant species. Additional samples at this site would be requested to test this hypothesis.

High numbers of Aponema have been previously reported from the Siboglinidae fields of the Håkon Mosby Mud Volcano, although with a much lower relative abundance (12-17\%) (Portnova, 2009; Van Gaever et al., 2009b). Apart from these studies, Aponema is usually reported with low numbers, or, at best, as subdominant to other genera (e.g. Lambshead et al., 2003; Zeppilli et al., 2011a). Another interesting case is that of Molgolaimus, a genus that was subdominant at the Pcc and Top microhabitats of Amsterdam (4.3\% for both microhabitats) as well as at the Biv, Pcc and Plam microhabitats of Napoli $(4.6 \%, 5.9 \%$ and $4.2 \%$, respectively). Molgolaimus differs from Aponema in having reflexed instead of outstretched ovaries, a feature that led Lorenzen (1994), in the most recent classification of freeliving nematodes, to place it in the family Desmodoridae, while previously they were both members of the same family (i.e. Molgolaimidae: Jensen, 1978). Apart from this small phylogenetic difference, the two genera are so similar in all other characteristics that it may be assumed that they also share similar physiological and ecological features such as tolerance to chemical stress, metabolism and ability to move or migrate (Peters, 1983; Soetaert et al., 2002). Molgolaimus has been often observed to be abundant in reduced conditions, supporting the hypothesis that it is an opportunistic genus capable of exploiting extreme environments such as mud volcanoes, hydrothermal vents and cold seeps (Vanreusel et al., 1997; Van Gaever et al., 2004). The dominance of Aponema at the Red microhabitat of Amsterdam clearly suggests that it is also a tolerant and opportunistic genus and that its similarities with Molgolaimus go beyond their external morphology.

The high abundance of Manganonema at the Pfar site is also surprising. This genus, although present in many oceans of the world (e.g. Vanhove et al., 1999; Netto et al., 2005; Danovaro et al., 2008), is considered a rare deep-sea genus as it never exceeds 2 to $3 \%$ (Fonseca et al., 2006; Zeppilli et al., 2011b). So far, it has been reported at hydrothermal vents, mud volcanoes, submarine canyons, polymetallic nodule deposits, cold-water corals and seamounts (e.g. Zeppilli et al., $2011 \mathrm{~b}$, and references therein), suggesting that this genus is able to colonize many different environments. This is further supported by the present study since Manganonema was found in several of the microhabitats sampled at both mud volcanoes. The high relative abundance of Manganonema found at the Pfar microhabitat $(5.5 \%)$ suggests that this genus might not be as rare as previously thought and that there might be specific, yet unexplored habitats where it thrives in high numbers. The fact that Manganonema sp. 2 was the only species among those with an average contribution $>1 \%$ that correlated, although negatively, with methane, may further suggest that the abundance of particular species in areas enriched with methane is an ecological compromise between their food requirements, their adaptations to the toxic environment and possibly the absence, due to toxicity, of competitors and predators.

Various authors have suggested that the penetration of meiofauna into deep-sea sediments is governed directly and primarily by the oxygenation of the sediment column (Shirayama, 1984; Alve and Bernhard, 1995), while others attributed more importance to food availability (Thiel, 1983; Lambshead et al., 1995; Vanreusel et al., 1995). Under seep conditions, the macrofaunal activity (e.g. root penetrations, burrowing) may provide islands of oxygen even deeper into the sediment $(>5 \mathrm{~cm})$ and thus are expected to influence the vertical distribution of microbial and smaller infaunal communities (Levin, 2005). Indeed, a deeper vertical penetration of meiofauna has been reported in a number of seep sites such as the Sagami Bay in central Japan, (Shirayama and Ohta, 1990), the western Mediterranean (Zeppilli et al., 2012) and the eastern Antarctic Peninsula (Hauquier et al., 2011). In the present study, nematodes penetrated deeper $(>5 \mathrm{~cm})$ not only at the Lam and Plam microhabitats, where root penetration of the tubeworms might have provided corridors of $\mathrm{O}_{2}$ transport into the sediment, but also at the other seep microhabitats (V. Kalogeropoulou, personal observation, 2010). However, because they also showed typical deep-sea vertical profiles at the top $5 \mathrm{~cm}$ of the sediment, more evidence is 
needed to clarify the vertical distribution patterns and their driving factors.

\subsection{Influence of seep heterogeneity on diversity}

The total number of meiofaunal taxa encountered in the present study (23 taxa) is relatively high when compared to other Mediterranean or worldwide studies (e.g. Gambi et al., 2010, and references therein); however, if one considers the different microhabitats separately, then the numbers ( 9 to 15 taxa) are within the ranges previously reported. For example, in surveys focusing specifically on cold-seep areas, Van Gaever et al. (2009b) reported 13 taxa at the Siboglinidae field of the Nyegga area in the North Sea while Zeppilli et al. (2011a) reported 15 taxa at terrace-like carbonate structures in the central Mediterranean. Similarly, Zeppilli et al. (2012) found 3 to 8 taxa in a western Mediterranean pockmark area. In the present study, nematodes were by far the dominant taxon at all microhabitats investigated. This is usually the case in most chemoautotrophic environments, although other taxa such as gnathostomulids or copepods have been also reported to prevail (Powell and Bright, 1981; Powell et al., 1983; Van Gaever et al., 2006; Zekely et al., 2006). Nevertheless, these exceptions are usually found in shallow areas, while the bulk of evidence, including the present study, indicates that in the deep-sea, cold-seep areas, particularly mud volcanoes, are always dominated by nematodes (e.g. Levin, 2005, and references therein). This is not surprising since nematodes are typically the dominant taxon in deepsea sediments (Lambshead and Boucher, 2003; Giere, 2009).

The comparison of diversity measures of the different microhabitats revealed that, similar to the abundance patterns, there is no consistent response of nematode diversity to the varying seep conditions. Napoli generally displayed higher diversity values compared to Amsterdam. However, one of its microhabitats (Lam) had a very low number of species, similar to the most species-poor microhabitat, namely the reduced sediments of Amsterdam. On the other hand, the number of species encountered at the Amsterdam far peripheral site was equally as high as the two most diverse microhabitats of Napoli. It should be mentioned here that the data analysed are rather unbalanced due to the uneven sampling effort within microhabitats and between the two regions (i.e. low number of replicates for some microhabitats; only one sample for the Pfar site). These constraints are often unavoidable in mensurative experiments (Underwood, 1996) and are very common in deep-sea surveys, particularly when advanced but expensive submersible technologies, such as ROVs, are involved. Nevertheless, the comparison of the Pfar site in the present study with sediments collected from different sites of the Mediterranean revealed no real differences in nematode species richness whatsoever (Danovaro et al., 2008). In a comparison of nematode communities from different shallow mud volcanoes in the central Mediterranean, Zeppilli et al. (2011a) found that gas seepage had a negative ef- fect on both meiofaunal abundance and the number of higher taxa, whereas seep conditions were beneficial for nematode diversity. Similarly, in a comprehensive review on global nematode patterns, Vanreusel et al. (2010b) reported that certain seep habitats, such as the well-oxygenated sediments underneath siboglinid tubeworm patches, were inhabited by a genus-rich nematode assemblage composed of genera similar to those of the slope sediments. The inverse correlation of nematode diversity with food indicates that the higher the additional chemical energy source the fewer the species that may respond significantly to the increased food availability, as suggested by Vanreusel et al. (2010a).

Beta diversity is a measure of the change in diversity among samples (Whittaker, 1972), and may provide a direct link between biodiversity at local scale ( $\alpha$-diversity) and the broader regional species pool ( $\gamma$-diversity). Thus, it is an important component of community ecology for understanding diversity patterns (Ellingsen and Gray, 2002; Anderson et al., 2011). Beta diversity studies have mainly focused on the larger mega- and macrofaunal organisms (Rex and Etter, 2010), but recently they have been applied successfully in meiofaunal studies as well (e.g. de Troch et al., 2001; Van Gaever et al., 2010; Sevastou et al., 2011; Leduc et al., 2012). In the present study, $\beta$-diversity analysis showed that the highest species turnover rate occurred between different microhabitats of the same mud volcano. Jumars (1976) first introduced the problem of scale in deep-sea ecology with subsequent studies, clearly indicating that diversity measures are indeed scale-dependent for a wide range of organisms and habitats. In a study on the influence of cold-seep habitat heterogeneity at different spatial scales along the Norwegian margin, Van Gaever et al. (2010) showed that the macro-scale (e.g. 10 s to 100 s of meters) contributed the most to nematode genus diversity. This result is very similar to the results from the present study as the within microhabitat, between microhabitats and between mud volcanoes complementarity analyses roughly correspond to the micro-, macro- and megascales from the Norwegian margin. Of course one cannot exclude that this may be a result of the different sampling efforts since it is well known that larger areas will reveal more species (Rosenzweig, 1995), a pattern which is also generally true for nematodes (Mokievsky and Azovsky, 2002; Lambshead, 2004, e.g. ). Nevertheless, in both of these studies, besides the higher genus or species turnover at the macro-scale, it was also evident that the contribution of the smaller and larger scales was also significant. Thus it can be concluded that all scales contribute to high nematode genus or species diversity and, as Vanreusel et al. (2010b) state, habitat heterogeneity is a major factor structuring nematode communities at seep environments.

\subsection{Is there evidence for a specialized fauna?}

The results from the present study support previous observations that species composition at cold seeps and mud 
volcanoes varies at different spatial scales, since not always the same species (or genera) were dominant or subdominant. The relatively high number of species that were restricted to a single microhabitat (unique species: $20.3 \%$ ) suggests a high potential for endemism. It should be noted, however, that in the present study, as with most other deep-sea ecological surveys, nematode species identifications were done as putative or "working" species (e.g. Sabatieria sp.1, Sabatieria sp.2, etc.), a practice that restrain comparative analyses with assemblages from different locations, except in the case when identifications are performed by the same research group. For this reason, identifications at the genus level is perhaps more appropriate. However, genus-level identification is also problematic since most genera have the potential to colonize a variety of deep-sea substrata and appear to be distributed worldwide (Vanreusel et al., 2010b). Nevertheless, although species identification is more labourintensive, expensive and requires considerable expertise, it remains the probable preferable way since meiofaunal diversity is expected to vary strongly with taxonomic resolution. In a comprehensive review on the worldwide distribution of deep-sea nematode species, Miljutin et al. (2010) reported that, from a total of 638 valid species, only 46 (7.2\%) could be considered as cosmopolitan. This also suggests that there is a great potential for endemism in the deep-sea, including cold seeps and mud volcanoes. To date, the few studies reporting nematode distribution patterns from cold-seep areas at the species level are rather confusing. At the Håkon Mosby Mud Volcano, Van Gaever et al. (2009b) found one single nematode species (Halomonhystera disjuncta) thriving with extremely high numbers in the bacterial mats. Since $H$. disjuncta has been often reported from shallow waters, it was initially suggested that it was capable of successfully colonizing different habitats. However, molecular analysis indicated that $H$. disjuncta may actually belong to a complex of cryptic species impossible to distinguish morphologically (Derycke et al., 2007; Fonseca et al., 2008). Another such example is the case of Sabatieria mortenseni, a species which is well known from shallow areas but also from the REGAB cold seep in the Gulf of Guinea, where it was dominant (Van Gaever et al., 2009a). The dominant species of the present study (Sabatieria sp.4) strongly resembles Sabatieria mortenseni (A. De Groote, personal communication, 2012), suggesting that remote seeps located at completely different geographic areas are possibly interconnected. However, based on the above example of Halomonhystera disjuncta, and without any clear molecular evidence, it is more likely that Sabatieria sp. 4 will be another cryptic species of the Sabatieria mortenseni complex. On the other hand, Aponema sp.1, which strongly dominated the reduced sediments of Amsterdam, does not look similar to any of the valid Aponema species. Moreover, it was never reported in high densities from the deep-sea; thus, it could be possible that this particular species may be restricted to the reduced sediments of Amsterdam. In addition, many of the other pu- tative species identified from the reduced samples appear to be new, suggesting that this microhabitat may offer unusual living conditions. Nevertheless, one should always keep in mind that the deep sea remains highly under-sampled, meaning that the probability of encountering new species with every new sample is very high. Furthermore, also taking into account the high number of singletons encountered in the present study, it may be likely that an increased sampling effort of deep-sea sediments may prove that Aponema sp. 1 is as equally widespread as other deep-sea species. All the above examples clearly suggest that it is very difficult to draw conclusions on endemism of cold-seep fauna based exclusively on morphology and without the use of molecular techniques.

\section{Conclusions}

The comparison of meiofaunal communities in two different mud volcanoes in the eastern Mediterranean showed high densities at Amsterdam, probably reflecting a higher seepage activity at the Anaximander mud field (Amsterdam mud volcano) compared to the Olimpi area (Napoli mud volcano). On the other hand, biomass values were an order of magnitude higher at Napoli, the main reason being an apparent shift in nematode size spectra towards longer and wider animals at Napoli.

In contrast to the standing stocks, the effects on nematode biodiversity were variable. At some seep microhabitats, species richness was significantly high while at others only few species were encountered. Although the highest species turnover was observed at the level of microhabitats, all sampling scales were found to significantly contribute to species richness, enhancing the biodiversity of nematode communities in the eastern Mediterranean and for seeps in general. Both the univariate and multivariate analysis showed that the spatial distribution of nematodes is mainly controlled by food availability and quality.

This study further supports previous observations that species composition of nematode communities varies significantly between seeps. The dominance of Aponema sp.1 and Sabatieria sp.4 at different microhabitats and the high relative abundance of Manganonema at one peripheral station suggests that nematode communities are patchily distributed and that each microhabitat may be characterized by a completely different assemblage, depending on specific environmental characteristics and the availability of recruits of nearby species that are able to thrive in such conditions.

The high morphological similarity between Sabatieria sp.4 and Sabatieria mortenseni, a cosmopolitan species which has been reported from many different substrata, including mud volcanoes, and the dissimilarity of Aponema sp.1 with any of the known Aponema species, together with the high densities of Manganonema at one of the stations, clearly suggest that both cosmopolitanism and endemism are possible in cold-seep environments. However, 
these ecosystems remain severely undersampled, supporting the need for more evidence to substantiate these hypotheses.

\section{Supplementary material related to this article is

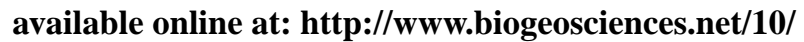 5381/2013/bg-10-5381-2013-supplement.pdf.}

Acknowledgements. The captain and crew of the R/V Pourquoi pas? as well as the pilots of the ROV Victor-6000 are warmly acknowledged for their dedicated assistance and for contributing to the success of the MEDECO cruise in 2007. This research was jointly funded by the EU projects HERMES (Hot Spot Ecosystem Research on the Margins of European Seas FP6, Contract No. GOCE-CT-2005-511234-1), HERMIONE (Hotspot Ecosystem Research and Man's Impact on European Seas FP7-ENV-2008-1, Contract No. 226354), the EU FP6 ERA-network MarinERA, REDECO (Regional Drivers of Ecosystem Change and its Influence on Deep-Sea populations in the Mediterranean), and by the Greek General Secretariat of Research and Technology, Ministry of Education and Religious Affairs.

Edited by: R. Danovaro

\section{References}

Alve, E. and Bernhard, J. M.: Vertical migratory response of benthic foraminifera to controlled oxygen concentrations in an experimental mesocosm, Mar. Ecol.-Prog. Ser., 116, 137-151, 1995.

Anderson, M. J., Crist, T. O., Chase, J. M., Vellend, M., Inouye, B. D., Freestone, A. L., Sanders, N. J., Cornell, H. V., Comita, L. S., Davies, K. F., Harrison, S. P., Kraft, N. J. B., Stegen, J. C., and Swenson, N. G.: Navigating the multiple meanings of diversity: a roadmap for the practicing ecologist, Ecol. Lett., 14, 19-28, 2011.

Andrassy, I.: Die Rauminhalts-und Gewichtsbestimmung der Fadenwürmer (Nematoden), Acta Zool. Hung., 2, 1-15, 1956.

Bernhard, J. M., Buck, K. R., Farmer, M. A., and Bowser, S. S.: The Santa Barbara Basin is a symbiosis oasis, Nature, 403, 7780, 2000.

Buck, K. R. and Barry, J. P.: Monterey Bay cold seep infauna: quantitative comparison of bacterial mat meiofauna with non-seep control sites, Cah. Biol. Mar., 39, 333-336, 1998.

Camerlenghi, A. and Pini, G. A.: Mud volcanoes, olistostromes and Argille scagliose in the Mediterranean region, Sedimentology, 56, 319-365, 2009.

Carney, R. S.: Consideration of the oasis analogy for chemosynthetic communities at Gulf of Mexico hydrocarbon vents, GeoMar. Lett., 14, 149-159, 1994.

Charlou, J., Donval, J., Zitter, T., Roy, N., Jean-Baptiste, P., Foucher, J., and Woodside, J.: Evidence of methane venting and geochemistry of brines on mud volcanoes of the eastern Mediterranean Sea, Deep-Sea Res. Pt. I, 50, 941-958, 2003.

Clarke, K. R. and Ainsworth, M.: A method of linking multivariate community structure to environmental variables, Mar. Ecol.Prog. Ser., 92, 205-219, 1993.
Clarke, K. R. and Gorley, R. N.: PRIMER v6: User Manual/Tutorial, PRIMER-E, Plymouth, 2006.

Cordes, E. E., Cunha, M. R., Galéron, J., Mora, C., Roy, K. O.L., Sibuet, M., Van Gaever, S., Vanreusel, A., and Levin, L. A.: The influence of geological, geochemical, and biogenic habitat heterogeneity on seep biodiversity, Mar. Ecol., 31, 51-65, 2010.

Corselli, C. and Basso, D.: First evidence of benthic communities based on chemosynthesis on the Napoli mud volcano (Eastern Mediterranean), Mar. Geol., 132, 227-239, 1996.

Coull, B. C. and Bell, S. S.: Perspectives of marine meiofaunal ecology, 189-216, Plenum Press, New York, 1979.

Danovaro, R., Fabiano, M., Albertelli, G., and Della Croce, N.: Vertical distribution of meiobenthos in bathyal sediments of the eastern Mediterranean Sea: Relationship with labile organic matter and bacterial biomasses, Mar. Ecol., 16, 103-116, 1995.

Danovaro, R., Tselepides, A., Otegui, A., and Della Croce, N.: Dynamics of meiofaunal assemblages on the continental shelf and deep-sea sediments of the Cretan Sea (NE Mediterranean): relationships with seasonal changes in food supply, Prog. Oceanogr., 46, 367-400, 2000.

Danovaro, R., Gambi, C., Lampadariou, N., and Tselepides, A.: Deep-sea nematode biodiversity in the Mediterranean basin: testing for longitudinal, bathymetric and energetic gradients, Ecography, 31, 231-244, 2008.

Danovaro, R., Dell'Anno, A., Pusceddu, A., Gambi, C., Heiner, I., and Mobjerg Kristensen, R.: The first metazoa living in permanently anoxic conditions, BMC Biol., 8, 30, 2010.

Davis, P. H. and Spies, R. B.: Infaunal benthos of a natural petroleum seep: study of community structure, Mar. Biol., 59, 31-41, 1980.

de Troch, M., Fiers, F., and Vincx, M.: Alpha and beta diversity of harpacticoid copepods in a tropical seagrass bed: the relation between diversity and species' range size distribution, Mar. Ecol.Prog. Ser., 215, 225-236, 2001.

Derycke, S., Backeljau, T., Vlaeminck, C., Vierstraete, A., Vanfleteren, J. R., Vincx, M., and Moens, T.: Spatiotemporal analysis of population genetic structure in Geomonhystera disjuncta (Nematoda, Monhysteridae) reveals high levels of molecular diversity, Mar. Biol., 151, 1799-1812, 2007.

Dimitrov, L.: Mud volcanoes-the most important pathway for degassing deeply buried sediments, Earth-Sci. Rev., 59, 49-76, 2002.

Ellingsen, K. E. and Gray, J. S.: Spatial patterns of benthic diversity: is there a latitudinal gradient along the Norwegian continental shelf?, J. Animal Ecol., 71, 373-389, 2002.

Fiala-Médioni, A. and Felbeck, H.: Autotrophic processes in invertebrate nutrition: bacterial symbiosis in bivalve molluscs, Comp. Physiol., 5, 49-69, 1990.

Findlay, S. E. G.: Small-scale spatial distribution of meiofauna on a mud- and sandflat, Estuar. Coast. Shelf S., 12, 471-484, 1981.

Fisher, C. R.: Chemoautotrophic and methanotrophic symbioses in marine invertebrates, Rev. Aquat. Sci., 2, 399-436, 1990.

Fonseca, G., Decraemer, W., and Vanreusel, A.: Taxonomy and species distribution of the genus Manganonema Bussau, 1993 (Nematoda: Monhysterida), Cah. Biol. Mar., 47, 189-203, 2006.

Fonseca, G., Derycke, S., and Moens, T.: Integrative taxonomy in two free-living nematode species complexes, Biol. J. Linn. Soc., 94, 737-753, 2008. 
Gambi, C., Lampadariou, N., and Danovaro, R.: Latitudinal, longitudinal and bathymetric patterns of abundance, biomass of metazoan meiofauna: importance of the rare taxa and anomalies in the deep Mediterranean Sea, Adv. Oceanogr. Limnol., 1, 167-197, 2010.

Giere, O.: Meiobenthology: the Microscopic Motile Fauna of Aquatic Sediments, Springer Verlag, Berlin-Heidelberg, 527 pp., 2009.

Hauquier, F., Ingels, J., Gutt, J., Raes, M., and Vanreusel, A.: Characterisation of the nematode community of a lowactivity cold seep in the recently ice-shelf free Larsen B area, eastern Antarctic Peninsula, PLoS ONE, 6, e22240, doi:10.1371/journal.pone.0022240, 2011.

Heip, C., Herman, P. J., and Soetaert, K.: Data Processing Evaluation and Analysis, Smithsonian Institution Press, Washington DC, London, 197-231, 1988.

Hill, M. O.: Diversity and evenness: a notation and its consequences, Ecology, 54, 427-431, 1973.

Hinrichs, K. U. and Boetius, A. B.: The Anaerobic Oxidation of Methane: New Insights in Microbial Ecology and Biogeochemistry, Springer-Verlag, Heidelberg, 457-477, 2002.

Holland, C., Etiope, G., Milkov, A., Michelozzi, E., and Favali, P.: Mud volcanoes discovered offshore Sicily, Mar. Geol., 199, 1-6, 2003.

Holland, C., Weber, T., and Etiope, G.: Acoustic scattering from mud volcanoes and carbonate mounds, J. Acoust. Soc. Am., 120, 3553-3565, 2006.

Jensen, P.: Revision of Microlaimidae, erection of Molgolaimidae fam. N., and remarks on the systematic position of Paramicrolaimus (Nematoda, Desmodorida), Zool. Scr., 7, 159-173, 1978.

Jensen, P.: Differences in microhabitat, abundance, biomass and body size between oxybiotic and thiobiotic free-living marine nematodes, Oecologia, 71, 564-567, 1987.

Jumars, P. A.: Deep-sea species diversity: does it have a characteristic scale?, J. Mar. Res., 34, 217-246, 1976.

Kojima, S.: Deep-sea chemoautosynthesis-based communities in the northwestern Pacific, J. Oceanogr., 58, 343-363, 2002.

Knoll, A. H. and Holland, H. D.: Oxygen and Proterozoic Evolution: An Update, 21-33, National Research Council, Washington, DC, 1995.

Kopf, A. J.: Significance of mud volcanism, Rev. Geophys, 40, 152, 2002.

Lambshead, P. J.: Marine nematode biodiversity, 436-467, CABI Publishing, 2004.

Lambshead, P. J. D. and Boucher, G.: Marine nematode deep-sea biodiversity - hyperdiverse or hype?, J. Biogeogr., 30, 475-485, 2003.

Lambshead, P. J. D., Ferrero, T. J., and Wolff, G. A.: Comparison of the vertical distribution of nematodes from two contrasting abyssal sites in the northeast Atlantic subject to different seasonal inputs of phytodetritus, Int. Rev. Ges. Hydrobio., 80, 327-332, 1995.

Lambshead, P. J. D., Brown, C. J., Ferrero, T. J., Hawkins, L. E., Smith, C. R., and Mitchell, N. J.: Biodiversity of nematode assemblages from the region of the Clarion-Clipperton Fracture Zone, an area of commercial mining interest, BMC Ecol., 3, 112, 2003.

Lampadariou, N. and Tselepides, A.: Spatial variability of meiofaunal communities at areas of contrasting depth and productivity in the Aegean Sea (NE Mediterranean), Prog. Oceanogr., 69, 1936, 2006.

Lampadariou, N., Tselepides, A., and Hatziyanni, E.: Deep-sea meiofaunal and foraminiferal communities along a gradient of primary productivity in the eastern Mediterranean Sea, Sci. Mar., 73, 337-345, 2009.

Leduc, D., Rowden, A. A., Bowden, D. A., Nodder, S. D., Probert, P. K., Pilditch, C. A., Duineveld, G. C. A., and Witbaard, R.: Nematode beta diversity on the continental slope of New Zealand: spatial patterns and environmental drivers, Mar. Ecol.-Prog. Ser., 454, 37, 2012.

Levin, L. A.: Ecology of cold seep sediments: interactions of fauna with flow, chemistry and microbes, Oceanogr. Mar. Biol. Ann. Rev., 43, 1-46, 2005.

Levin, L. A. and Mendoza, G. F.: Community structure and nutrition of deep methane-seep macrobenthos from the North Pacific (Aleutian) Margin and the Gulf of Mexico (Florida Escarpment), Mar. Ecol., 28, 131-151, 2007.

Levin, L. A., James, D. W., Martin, C. M., Rathburn, A. E., Harris, L. H., and Michener, R. H.: Do methane seeps support distinct macrofaunal assemblages? Observations on community structure and nutrition from the northern California slope and shelf, Mar. Ecol.-Prog. Ser., 208, 21-39, 2000.

Levin, L. A., Ziebis, W., Mendoza, G. F., Growney, V. A., Tryon, M. D., Brown, K. M., Mahn, C., Gieskes, J. M., and Rathburn, A. E.: Spatial heterogeneity of macrofauna at northern California methane seeps: influence of sulfide concentration and fluid flow, Mar. Ecol.-Prog. Ser., 265, 123-139, 2003.

Loncke, L. and Mascle, J.: Mud volcanoes, gas chimneys, pockmarks and mounds in the Nile deep-sea fan (Eastern Mediterranean): Geophysical evidences, Mar. Petrol. Geol., 21, 669-689, 2004.

Lorenzen, S.: The Phylogenetic Systematics of Free-Living Nematodes, vol. 383, The Ray Society, London, 1994.

Lykousis, V., Alexandri, S., Woodside, J., de Lange, G., Dählmann, A., Perissoratis, C., Heeschen, K., Ioakim, C., Sakellariou, D., Nomikou, P., Rousakis, G., Casas, D., Ballas, D., and Ercilla, G.: Mud volcanoes and gas hydrates in the Anaximander mountains (Eastern Mediterranean Sea), Mar. Petrol. Geol., 26, 854-872, 2009.

Menot, L., Galéron, J., Olu, K., Caprais, J.-C., Crassous, P., Khripounoff, A., and Sibuet, M.: Spatial heterogeneity of macrofaunal communities in and near a giant pockmark area in the deep Gulf of Guinea, Mar. Ecol., 31, 78-93, 2010.

Miljutin, D. M., Gad, G., Miljutina, M. M., Mokievsky, V. O., Fonseca-Genevois, V., and Esteves, A. M.: The state of knowledge on deep-sea nematode taxonomy: how many valid species are known down there?, Mar. Biodiv., 40, 143-159, 2010.

Milkov, A. V.: Worldwide distribution of submarine mud volcanoes and associated gas hydrates, Mar. Geol., 167, 29-42, 2000.

Mokievsky, V. and Azovsky, A.: Re-evaluation of species diversity patterns of free-living marine nematodes, Mar. Ecol.-Prog. Ser., 238, 101-108, 2002.

Montagna, P. A. and Spies, R. B.: Meiofauna and chlorophyll associated with Beggiatoa mats of a natural submarine petroleum seep, Mar. Environ. Res., 16, 231-242, 1985.

Neira, C., Sellanes, J., Levin, L. A., and Arntz, W. E.: Meiofaunal distributions on the Peru margin: relationship to oxygen and organic matter availability, Deep-Sea Res. Pt. I, 48, 2453-2472, 
2001.

Netto, S. A., Gallucci, F., and Fonseca, G. F. C.: Meiofauna communities of continental slope and deep-sea sites off SE Brazil, Deep-Sea Res. Pt. I, 52, 845-859, 2005.

Olu, K., Lance, S., Sibuet, M., Henry, P., Fiala-Médioni, A., and Dinet, A.: Cold seep communities as indicators of fluid expulsion patterns through mud volcanoes seaward of the Barbados accretionary prism, Deep-Sea Res., 44, 811-841, 1997.

Olu-Le Roy, K., Sibuet, M., Fiala-Médioni, A., Gofas, S., Salas, C., Mariotti, A., Foucher, J., and Woodside, J.: Cold seep communities in the deep eastern Mediterranean Sea: composition, symbiosis and spatial distribution on mud volcanoes, Deep-Sea Res. Pt. I, 51, 1915-1936, 2004.

Pape, E., Bezerra, T. N., Vanneste, H., Heeschen, K., Moodley, L., Leroux, F., van Breugel, P., and Vanreusel, A.: Community structure and feeding preference of nematodes associated with methane seepage at the Darwin mud volcano (Gulf of Cadiz), Mar. Ecol.-Prog. Ser., 438, 71-83, 2011.

Paull, C. K., Hecker, B., Commeau, R., Freeman-Lynde, R. P., Neumann, C., Corso, W. P., Golubic, S., Hook, J. E., Sikes, E., and Curray, J.: Biological communities at the Florida escarpment resemble hydrothermal vent taxa, Science, 226, 965-967, 1984.

Peters, R. H.: The Ecological Implications of Body Size, Cambridge University Press, Cambridge, UK, 1983.

Platt, H. M. and Warwick, R. M.: Freeliving Marine Nematodes. Part I. British Enoplids, Synopses of the British Fauna (New Series), Vol. 28, Cambridge University Press, Cambridge, 1983.

Platt, H. M. and Warwick, R. M.: Freeliving Marine Nematodes, Part II. British Chromadorids, Synopses of the British Fauna (New Series), Vol. 38, edited by: Brill, E. J. and Backhuys, W., Leiden, 1988.

Portnova, D.: Free-living nematodes from the deep-sea Håkon Mosby Mud Volcano, including the description of two new and three known species, Zootaxa, 2096, 197-213, 2009.

Powell, E. S. and Bright, T. J.: A thiobios does exist - Gnathostomulid domination of the canyon community at the East Flower Garden brine seep, Int. Rev. Ges. Hydrobio., 66, 675-683, 1981.

Powell, E. N., Bright, T. J., Woods, A., and Gittings, S.: Meiofauna and the thiobios in the east flower garden brine seep, Mar. Biol., 73, 269-283, 1983.

R Core Team: R: A Language and Environment for Statistical Computing, R Foundation for Statistical Computing, Vienna, Austria. ISBN 3-900051-07-0, available at: http://www.R-project.org/, 2013.

Rex, M. A. and Etter, R. J.: Deep-sea biodiversity: pattern and scale, Harvard University Press, Cambridge, ISBN 978-0-674-036079, 2010.

Ritt, B., Pierre, C., Gauthier, O., Wenzhöfer, F., Boetius, A., and Sarrazin, J.: Diversity and distribution of cold-seep fauna associated with different geological and environmental settings at mud volcanoes and pockmarks of the Nile Deep-Sea Fan, Mar. Biol., 158, 1187-1210, 2011.

Ritt, B., Desbruyres, D., Caprais, J. C., Gauthier, O., Ruffine, L., Buscail, R., Olu-Le Roy, K., and Sarrazin, J.: Seep communities from two mud volcanoes in the deep eastern Mediterranean Sea: faunal composition, spatial patterns and environmental control, Mar. Ecol.-Prog. Ser., 466, 93-119, 2012.

Rosenzweig, M. L.: Species diversity in space and time, Cambridge University Press, Cambridge, 1995.
Savini, A., Malinverno, E., Etiope, G., Tessarolo, C., and Corselli, C.: Shallow seep-related seafloor features along the Malta plateau (Sicily channel - Mediterranean Sea): Morphologies and geo-environmental control of their distribution, Mar. Petrol. Geol., 26, 1831-1848, 2009.

Sellanes, J., Neira, C., Quiroga, E., and Teixido, N.: Diversity patterns along and across the Chilean margin: a continental slope encompassing oxygen gradients and methane seep benthic habitats, Mar. Ecol., 31, 111-124, 2010.

Sergeeva, N. G. and Gulin, M. B.: Meiobenthos from an active methane seepage area in the NW Black Sea, Mar. Ecol., 28, 152 159, 2007.

Sevastou, K., Lampadariou, N., and Eleftheriou, A.: Meiobenthic diversity in space and time: The case of harpacticoid copepods in two Mediterranean microtidal sandy beaches, J. Sea Res., 66, 205-214, 2011.

Shirayama, Y.: Vertical distribution of meiobenthos in the sediment profile in bathyal, abyssal and hadal deep sea systems of the western Pacific, Oceanol. Acta, 7, 123-129, 1984.

Shirayama, Y. and Ohta, S.: Meiofauna in a cold-seep community off Hatsushima, central Japan, J. Oceanogr. Soc. Japan, 46, 118 124, 1990.

Sibuet, M. and Olu, K.: Biogeography, biodiversity and fluid dependence of deep-sea cold-seep communities at active and passive margins, Deep-Sea Res. Pt. II, 45, 517-567, 1998.

Sibuet, M. and Olu-LeRoy, K.: Cold Seep Communities on Continental Margins: Structure and Quantitative Distribution Relative to Geological and Fluid Venting Patterns, Springer-Verlag, Germany, 235-251, 2002.

Soetaert, K. and Heip, C.: Nematode assemblages of deep-sea and shelf break sites in the North Atlantic and Mediterranean Sea, Mar. Ecol.-Prog. Ser., 125, 171-183, 1995.

Soetaert, K., Muthumbi, A., and Heip, C.: Size and shape of ocean margin nematodes: morphological diversity and depth-related patterns, Mar. Ecol.-Prog. Ser., 242, 179-193, 2002.

Soltwedel, T., Portnova, D., Kolar, I., Mokievsky, V., and Schewe, I.: The small-sized benthic biota of the Håkon Mosby Mud Volcano (SW Barents Sea slope), J. Marine Syst., 55, 271-290, 2005.

Suess, E., Carson, B., Ritger, S. D., Moore, J. C., Jones, M. L., Kulm, L. D., and Cochrane, G. R.: Biological communities at vent sites along the subduction zone off Oregon, Bull. Biol. Soc. Washington, 6, 475-484, 1985.

Thiel, H.: Meiobenthos and Nanobenthos of the Deep-Sea, Wiley, New York, 167-230, 1983.

Tselepides, A. and Lampadariou, N.: Deep-sea meiofaunal community structure in the Eastern Mediterranean: are trenches benthic hotspots?, Deep-Sea Res. Pt. I, 51, 833-847, 2004.

Tselepides, A., Lampadariou, N., and Hatziyanni, E.: Distribution of meiobenthos at bathyal depths in the Mediterranean Sea. A comparison between sites of contrasting productivity, Sci. Mar., 68, 39-51, 2004.

Tunnicliffe, V., Juniper, S. K., and Sibuet, M.: Reducing Environments of the Deep-Sea Floor, Elsevier, Amsterdam, 81-110, 2003.

Underwood, A. J.: Experiments in Ecology: Their Logical Design and Interpretation Using Analysis of Variance, Cambridge University Press, Cambridge, 1996. 
Valentine, D. L.: Biogeochemistry and microbial ecology of methane oxidation in anoxic environments: a review, Antonie Leeuwenhoek, 81, 271-282, 2002.

Valentine, D. L. and Reeburgh, W. S.: New perspectives on anaerobic methane oxidation, Environ. Microbiol., 2, 477-484, 2000.

Van Dover, C. L.: The Ecology of Deep-Sea Hydrothermal Vents, Princeton New Jersey: Princeton University Press, 2000.

Van Gaever, S., Vanreusel, A., Hughes, J. A., Bett, B. J., and Kiriakoulakis, K.: The macro- and micro-scale patchiness of meiobenthos associated with the Darwin Mounds (north-east Atlantic), J. Mar. Biol. Assoc. UK, 84, 547-556, 2004.

Van Gaever, S., Moodley, L., de Beer, D., and Vanreusel, A.: Meiobenthos at the Arctic Håkon Mosby Mud Volcano, with a parental-caring nematode thriving in sulphide-rich sediments, Mar. Ecol.-Prog. Ser., 321, 143-155, 2006.

Van Gaever, S., Galéron, J., Sibuet, M., and Vanreusel, A.: Deep-sea habitat heterogeneity influence on meiofaunal communities in the Gulf of Guinea, Deep-Sea Res. Pt. II, 56, 2259-2269, 2009a.

Van Gaever, S., Olu, K., Derycke, S., and Vanreusel, A.: Metazoan meiofaunal communities at cold seeps along the Norwegian margin: Influence of habitat heterogeneity and evidence for connection with shallow-water habitats, Deep-Sea Res. Pt. I, 56, 772785, 2009b.

Van Gaever, S., Raes, M., Pasotti, F., and Vanreusel, A.: Spatial scale and habitat-dependent diversity patterns in nematode communities in three seepage related sites along the Norwegian Sea margin, Mar. Ecol., 31, 66-77, 2010.

Vanhove, S., Arntz, W., and Vincx, M.: Comparative study of the nematode communities on the southeastern Wedell Sea shelf and slope (Antarctica), Mar. Ecol.-Prog. Ser., 181, 237-256, 1999.

Vanreusel, A., Vincx, M., Schram, D., and van Gansbeke, D.: On the vertical distribution of the metazoan meiofauna in shelf-break and upper slope habitats of the NE Atlantic, Int. Rev. Ges. Hydrobio., 80, 313-326, 1995.

Vanreusel, A., van de Bossche, I., and Thiermann, F.: Free living marine nematodes from hydrothermal sediments: similarities with communities from diverse reduced habitats, Mar. Ecol.Prog. Ser., 157, 207-219, 1997.

Vanreusel, A., De Groote, A., Gollner, S., and Bright, M.: Ecology and Biogeography of Free-Living Nematodes Associated with Chemosynthetic Environments in the Deep Sea: A Review, PLoS ONE, 5, e12449, doi:10.1371/journal.pone.0012449, 2010a.
Vanreusel, A., Fonseca, G., Danovaro, R., Silva, M. C. d., Esteves, A. M., Ferrero, T., Gad, G., Galtsova, V., Gambi, C., Genevois, V. d. F., Ingels, J., Ingole, B., Lampadariou, N., Merckx, B., Miljutin, D., Miljutina, M., Muthumbi, A., Netto, S., Portnova, D., Radziejewska, T., Raes, M., Tchesunov, A., Vanaverbeke, J., van Gaever, S., Venekey, V., Bezerra, T. N., Flint, H., Copley, J., Pape, E., Zeppilli, D., Martinez, P. A., and Galéron, J.: The contribution of deep-sea macrohabitat heterogeneity to global nematode diversity, Mar. Ecol., 31, 6-20, 2010 b.

Warwick, R. M., Platt, H. M., and Somerfield, P. J.: Freeliving Marine Nematodes, Part III, Monhysterids, Synopses of the British Fauna (New Series), Vol. 53, Linean Society, London and Estuarine and Coastal Sciences Association, Shrewsbury, 1998.

Whittaker, R. H.: Evolution and measurement of species diversity, Taxon, 21, 213-251, 1972.

Wieser, W.: Benthic studies in Buzzards bay. II. The meiofauna, Limnol. Oceanogr., 5, 121-137, 1960.

Zekely, J., Van Dover, C., Nemeschkal, H., and Bright, M.: Hydrothermal vent meiobenthos associated with mytilid mussel aggregations from the Mid-Atlantic Ridge and the East Pacific Rise, Deep-Sea Res. Pt. I, 53, 1363-1378, http://www.sciencedirect. com/science/article/pii/S0967063706001439, 2006.

Zeppilli, D., Mea, M., Corinaldesi, C., and Danovaro, R.: Mud volcanoes in the Mediterranean Sea are hot spots of exclusive meiobenthic species, Prog. Oceanogr., 91, 260-272, 2011 a.

Zeppilli, D., Vanreusel, A., and Danovaro, R.: Cosmopolitanism and biogeography of the genus Manganonema (Nematoda: Monhysterida) in the deep sea, Animals, 1, 291-305, 2011 b.

Zeppilli, D., Canals, M., and Danovaro, R.: Pockmarks enhance deep-sea benthic biodiversity: a case study in the western Mediterranean Sea, Divers. Distrib., 18, 832-846, 2012.

Zitter, T., Huguen, C., and Woodside, J.: Geology of mud volcanoes in the eastern Mediterranean from combined sidescan sonar and submersible surveys, Deep-Sea Res. Pt. I, 52, 457-475, 2005. 